Erdey László

\title{
Az ágazaton belüli kereskedelem az elméleti magyarázatok és az empirikus vizsgálatok tükrében
}

A több mint negyed századig uralkodó, modern kereskedelmi elméletnek számító Heckscher-Ohlin (HO) modellt a XX. század második felében egyre több kihívás érte. A tökéletes versenyt, állandó skálahozadékot és homogén termékeket feltételező, 2*2*2-es (termék-tényező-ország), eleganciáját technikai egyszerüségében hordozó modell, úgy tünt, két jelentősebb területen nem kínál megfelelő válaszokat az empirikus tények magyarázatához. A modell konklúzióját, azaz hogy az országoknak azoknak a termékeknek a termelésében lesz komparatív előnyük, amelyek előállításához intenzíven használják az országban relatív bőségben rendelkezésre álló termelési tényezőt, elöször a Leontief-paradoxon', majd az ágazaton belüli kereskedelem empirikus tényei tették kétségessé. ${ }^{2}$ A tanulmány ez utóbbi jelenséggel foglalkozik, első részében bemutatva és rendszerezve a jelenség legjelentősebb elméleti modelljeit, a másodikban pedig - a területen folyó empirikus vizsgálatok alapján - az intraindusztriális kereskedelmet befolyásoló legfontosabb tényezőket.

\section{Az ágazaton belüli kereskedelem „felbukkanása”}

Az iparágon-belüli kereskedelemre (IIT) ${ }^{3}$ először az 1960-as években kezdett jelentősebb figyelem irányulni Verdoorn (1960) és Dréze $(1960,1961)$ kutatásai kapcsán. Az Európai Gazdasági Közösség kialakítása során az volt az általános várakozás, hogy a tagok közötti kereskedelem liberalizációja erőteljes interindusztriális specializációt hoz létre az országok gazdaságszerkezetében, fóként az egyes országok hagyományosan sikeres exportágazataiban, elörevetítve azt, hogy a legfejlettebb országok a magas hozzáadott értéket képző ágazatokra szakosodnak, míg a kevésbé fejlettek az elöbbiek által meg- vagy elhagyott szektorokban találják meg a helyüket. Verdoorn a Benelux-államok esetében, illetve Dréze mind a hat tagállamot vizsgálva arra a következtetésre jutott, hogy a vámunió létrehozása döntően nem ágazatok közötti, hanem ágazaton belüli szakosodással járt együtt, jelentősen ösztönözve a hasonló termékek kétirányú forgalmát. Az alkalmazkodási költségek pedig ebben az esetben jóval alacsonyabbak.

Több hipotézis is felmerült ezekben az időkben, amelyek alkalmasnak tüntek azágazaton belüliáramlásokmagyarázatára, ezekközüliskiemelkedikDréze-é(uo.), akia növekvő

\footnotetext{
${ }^{1}$ Ld. Leontief (1953)

2 Leamer (1992) szerint a Leontief paradoxon és az ágazaton belüli kereskedelem jelentőségének Grubel-Lloydféle demonstrációja volt az a két döntő fontosságú empirikus felfedezés, amely alapvetően megváltoztatta a közgazdászok nemzetközi kereskedelemmel kapcsolatos meglátásait.

${ }^{3}$ A jelenség leírására az ágazaton belüli, iparágon belüli és intraindusztriális kereskedelem (IIT-Intra-industry Trade) egyenértékü kifejezéseket használom a tanulmány során.
}

Erdey László egyetemi adjunktus a Debreceni Egyetem Közgazdaságtudományi Karának Világgazdaság és Nemzetközi Kapcsolatok Tanszékén.E-mail: erdeyl@dragon.klte.hu. 
skálahozadéknak és a termékmegkülönböztetésnek, Linderé (1961), aki a fogyasztási szerkezetek hasonlóságainak, illetve Vernoné (1966), aki a nemzetközi termékéletciklusnak tulajdonította ezt a jelenséget.

Az iparágon belüli kereskedelem elnevezést először Balassa (1966) alkalmazta ${ }^{4}$ és mérésére is ő tett először javaslatot. A téma utána sokáig érintetlenül hevert, a fordulatot Grubel és Lloyd 1975-ös könyve hozta, amely a jelenséggel kapcsolatban olyan kérdéseket vetett fel, amelyeket nem lehetett a neoklasszikus kereskedelmi elméletekkel megmagyarázni és amelytől kezdve „, további kutatások elválasztották a jelenséget a gazdasági integrációtól, rámutatva expanzív növekedésére a fejlett országok között a feldolgozóipar jelentős részében, függetlenül a vám-akadályoktól vagy azok változástól...” (Ethier 1982:389) A szerzők nem állítottak fel formális modellt, azonban helyesen mutattak rá, hogy a növekvő skálahozadék, a monopolisztikus verseny és az elhelyezkedés elmélet (location theory) valószínűleg fontos szerepet játszanak a jelenség magyarázatában. Fontos, hogy az intraindusztriális kereskedelemhez vezető független okokként azonosították a horizontális és a vertikális termékdifferenciációt.

A formális elméleti modellek kialakítására irányuló törekvések az iparágon-belüli kereskedelemnek - már Grubel és Lloyd által is körvonalazott - az 1. ábrán megtekinthető osztályozásához és elméleteihez vezettek. Mielőtt ezekre rátérnénk, érdemes azonban megismerkedni a korai magyarázatokkal is, amelyeket összefoglalása során felhasználom Grubel (1967) és Deardorff (1984) kategóriáit, megkülönböztetve a homogén és a differenciált termékek ágazaton belüli kereskedelmét.

\section{Homogén termékek}

a) Határmenti kereskedelem: ez a típusú áramlás tulajdonképpen szorosan köthető a külkereskedelemből kimaradó javaknak azon kategóriájához, ahol a nemkompetitívjelleg a termékek fajlagosan magas fuvarozási költségeiből adódik (pl. homok, kavics stb.). Ezek a költségek egy hosszabb határszakaszon a javak kétirányú áramlásához vezethetnek, ha az országon belülről való szállítás a földrajzi távolság miatt drágább, mint a szomszédos kereskedelmi partnertől.

b) Reexport ügyletek: a külkereskedelmi ügyletek egy jelentős csoportját alkotják, egy import és egy export ügylet összekapcsolásából adódnak. Témánk szempontjából nyilván a közvetett formának van jelentősége, hiszen az áramlások csak ilyenkor jelennek meg a reexportőr ország kereskedelmi statisztikáiban. Motivációjuk nagyon sokrétű lehet, az egyszerü haszonszerzésen túl indokolhatja az exportőr és az importőr közötti kereskedelmi, diplomáciai kapcsolatok hiánya, az információk elégtelensége stb. Bizonyos területek, országok mint Hongkong, Szingapúr földrajzi helyzetük előnyeit kihasználva válnak ezen ügyletek specialistáivá.

c) A kereskedelemben megnyilvánuló ciklikus jelleg: ha az adott termék keresletében vagy kínálatában érvényesül a ciklikusság vagy szezonalitás, és a periódusok két ország esetében eltérőek, valamint a raktározási költségek meghaladják a fuvarköltségeket, ágazaton belüli kereskedelem alakulhat ki, Grubel (1967) és Deardorff (uo.) a mezőgazdasági termékek és az elektromos áram példáját emelik ki ennél a típusnál.

${ }^{4}$ Balassa az EGK vizsgálatakor szintén arra a következtetésre jutott, hogy a vámcsökkentés a várakozásokkal ellentétben nem az iparágak közötti, hanem az intraindusztriális kereskedelmet ösztönzi inkább. 
d)Stratégiaikereskedelem:alapját Brander(1981)viszonosdömping elmélete adja ${ }^{5}$,ahol két nyitott ország monopolistái exportálni kezdenek egymás piacára, így duopolisztikussá alakítva az iparági szerkezetet.

\section{Differenciált termékek}

A megkülönböztetés alapja lehet a származási ország (ld. Armington-hipotézis ${ }^{6}$ ) vagy a termelők képessége a termékdifferenciációra, amelyről, akárcsak a növekvő skálahozadék szerepéről, a következő részben esik bővebben szó.

\section{Az új kereskedelmi elméletek ${ }^{7}$}

A hagyományos, komparatív előnyökön alapuló kereskedelmi elméletek szerint a nemzetközi munkamegosztás az országok között fennálló relatív termelékenységi, tényezöellátottság-beli különbségekkel magyarázható. A Heckscher-Ohlin-Samuelson ${ }^{8}$ modell a nemzetközi kereskedelem szerkezetének jellemzőit illetően több lényeges következtetést von le: a) a kereskedelem, termelési tényezőiket tekintve, egymástól különböző országok között fog zajlani, b) a kereskedelem áruösszetétele tükrözni fogja az országok relatív tényezőellátottsági viszonyait, c) a relatív tényezőárak megfelelő feltételek mellett ${ }^{9}$ konvergálnak a kereskedelmi partnerek között, d) a kereskedelem ágazatok között zajlik.

Az empirikus tapasztalatok azonban azt mutatják, hogy a nemzetközi kereskedelem nagy része hasonló termelékenységi szinten lévő vagy tényezőadottságokkal rendelkező országok között folyik és jelentős az ágazaton belüli áramlások súlya.

A nemzetközi közgazdaságtanban a fenti ellentmondások hatására kezdtek el kibontakozni az ún. új kereskedelmi elméletek, amelyek a hagyományos modelleket a tökéletes verseny feltételezésének oldaláról feszítik szét. A tökéletlenségek származhatnak a keresleti és a kínálati oldalról egyaránt, ezek megismeréséhez érdemes megvizsgálni az intraindusztriális kereskedelem különböző formáit. A részletes elemzést megelőzően arra is fel kell hívni a figyelmet, hogy míg az új kereskedelmi elméletek, illetve az új gazdasági földraj $\mathrm{z}^{10}$ szakít a tradicionális elméletekkel, a kezdetektől fogva jelen vannak olyan törekvések, amelyek az ágazaton belüli kereskedelmet a komparatív előnyök elméleti keretein belül magyarázzák.

Az új kereskedelmi elméletek alapját a korábbi modellektől eltérő feltételezések adják, melyek közül a legfontosabb a termékdifferenciáció, a növekvő skálahozadék és a tökéletlen verseny a keresleti vagy a kínálati oldalon. Döntően három stilizált tényre való magyarázatkeresésként jöttek létre, ezek i) a kereskedelemnek a termelést meghaladó növekedési üteme, ii) a fejlett országok egymás közötti kereskedelmének magas aránya a világkeres-

${ }^{5}$ ld. később

${ }^{6}$ A hipotézis lényege, hogy a fogyasztók a különböző országokból származó termékeket nem tekintik tökéletes helyettesítő termékeknek és különböző okoknál fogva inkább a hazai vagy a külföldi terméket választják. Ld. Armington, P. S. (1969): A Theory of Demand for Products Distinguished by Place and Production, IMF Staff Papers, 16, 159-178. o.

${ }^{7}$ New Trade Theory

${ }^{8}$ Eli Heckscher és Bertil Ohlin meglátásait Paul A. Samuelson fejlesztette matematikai modellé

${ }^{9}$ pl. specializáció, termékár-kiegyenlítődés, a munkaerő hasonló képzettsége, azonos termelési eljárások (technológia), a kereskedelmi akadályok hiánya

${ }^{10}$ New Economic Geography 
kedelemben, illetve iii) az iparosodott országok közötti jelentős mértékű ágazaton belüli kereskedelem.

Az új modellek első generációja főként a horizontális IIT-t magyarázza, azaz a hasonló minőségü - de a fogyasztók szempontjából fontos, egyéb karakterisztikák szín, dizájn stb. alapján differenciált termékek párhuzamos exportját és importját.

\section{Az ágazaton belüli kereskedelem elméletei}

\section{A horizontális ágazaton belüli kereskedelem}

A horizontális IIT ${ }^{11}$ jelenlétét kimutató fontosabb tanulmányok első csoportja Krugman $(1979,1981)$ és Lancaster $(1979,1980)$ nevéhez füződik. Közös jellemzőjük, hogy modelljeik a chamberlini monopolisztikus versenyre épülnek, és hasonló feltevésekkel élnek a technológiát és az iparági szerkezetet illetően. Feltételezik az iparágon belüli cégek magas számát, a növekvő belső skálahozadékot, a belépési és kilépési korlátok hiányát. A vállalatok ugyanazzal a technológiávalállítanak elő horizontálisan differenciált termékeket, úgy, hogy mindegyik profitmaximalizáló cég viszonylag alacsony szintü belső gazdaságossággal rendelkezik, emellett a többi vállalat ár- és termékstratégiáját konstansként kezelik. Egyik változatban sincs olyan termékvariáció, amelyet a fogyasztók összessége a többi felett állóként fogadna el.

A két szerző modelljei között a döntő különbség azonban mégis a kereslet megragadásában van: míg Krugmannál a fogyasztó a változatosságot kedveli ${ }^{12}$, preferenciái úgy alakulnak, hogy a terméknek annyi különbözö változatát szeretné fogyasztani, amennyi csak lehetséges, addig a Lancaster-féle fogyasztók mindegyikének megvan a saját ideális terméktípusa ${ }^{13}$, a preferenciák eloszlása az összes változat között egyenletes ${ }^{14}$.

Mindkét és a későbbi hasonló modellek alapján arra számíthatunk, hogy a vállalatok olyan termékváltozatok elóállítására specializálódnak, amelyeket egyetlen másik cég sem gyárt, és amelyekre mindkét országban kereslet van, ez horizontális ágazaton belüli kereskedelemhez vezet, mégpedig legintenzívebben az egymáshoz gazdaságilag hasonló országok ${ }^{15}$ között. Másrészről pedig maguk az intraindusztriális áramlások növelik a gazdaságok hasonlóságát.

Az ezekben az években megszülető további IIT-modellek ${ }^{16}$ sajátossága, hogy szintén a monopolisztikus verseny koncepciójára építenek, illetve Ethier (1982), Helpman (1983, 1985), Helpman és Krugman (1985, 11. fejezet) kivételével a differenciált végtermékeket választják elemzésük alapjául, utóbbiak a közbülső termékek növekvő skálahozadékon alapuló kereskedelmének elemzésére is kitérnek; egy viszonylag új modell e területen Lüthje (2001) nevéhez köthetö ${ }^{17}$.

\footnotetext{
${ }^{11}$ HIIT

12 Love of variety approach, a megközelités Spence (1976), illetve Dixit és Stiglitz (1977) tanulmányára épít.

${ }^{13}$ Ideal variety approach, a Lancaster-féle (1979) "új fogyasztói elmélet” (new consumer's theory) alapján. Helpman (1981) modellje is ezen alapszik. Megfelelő feltételekkel a preferenciák eloszlására nézve az aggregátumok szintjén hasonló prezentációt nyújt, mint a változatosságkedvelö (love of variety) megközelítés (ld. Helpman és Krugman 1985)

${ }_{14}$ A két különböző modelltípust szokás neo-Chamberlini és neo-Hotellingi címkékkel is illetni.

${ }^{15}$ A hasonlóság és különbözőség mérésére a cikk második felében térek ki részletesebben.

${ }^{16}$ ld. pl. még Dixit és Norman (1980), Helpman (1981)

${ }_{17}$ Lüthje (2001) elmélete kiterjeszthető a vertikálisan differenciált közbülső termékekre is.
} 
Mindegyik modellről elmondható, hogy a kereskedelem előnyeit és a jövedelemeloszlásra gyakorolt hatását illetően világos konklúziókra jut. A kereskedelem haszna abból származik, hogy az output a kereskedelemmel nő az autarch helyzethez képest, a jövedelemeloszlás sajátossága pedig az, hogy ellentétben a HO-modellel, egy ország minden fogyasztója kedvezőbb helyzetbe kerülhet a kereskedelem révén. A kereskedelem szerkezetét illetően azonban ezek az elméletek nem tudnak megfelelő predikciókkal szolgálni.

$\mathrm{Az}$ inter- és intraindusztriális kereskedelem magyarázatainak összekapcsolása Krugman (1980), Helpman (1981), illetve Helpman és Krugman (1985) nevéhez füződik, az irodalomban ezzel leggyakrabban Chamberlin-Heckscher-Ohlin(-Samuelson) (CHOS) modellelnevezésalatttalálkozhatunk. ACHOS-elméletazelőbbmegismertfeltételezések ${ }^{18}$ mellett figyelembe veszi a tényezőellátottságot is.

A horizontális megkülönböztetés miatt a fogyasztók számára a termék különböző változatai érhetők el. A nemzetközi kereskedelem növeli a piacot, így a termékválasztékot is, és valószínűleg növekvő skálahozadékhoz vezet. A modell predikciója az, hogy minél alacsonyabb egy iparágban a hatékony minimális méret ${ }^{19}$ (minél nagyobb a vállalatok, így a termékváltozatok száma), annál nagyobb a HIIT. Az országok közötti gazdasági különbségek az ágazatok közötti, míg a hasonlóság inkább az ágazaton belüli kereskedelemre van ösztönző hatással. Mindezekből következően Észak fejlett országai között a kereskedelem elsősorban iparágon belüli lesz, kihasználva a méretgazdaságosság előnyeit - feltételezve azt, hogy a keresleti oldalon a változatosság iránti igény összefügg a jövedelemmel, illetve hogy a kínálati oldalon a differenciált termékek tőkeigénye nagyobb, mint a homogéneké. AzÉszak és Dél közötti kereskedelmet pedig döntően a relatív tényezőellátottsági különbségeken alapuló, iparágak közötti áramlások fogják meghatározni.

Az alkalmazkodási költségek az intraindusztriális csere esetében várhatóan jóval alacsonyabbak lesznek, mint az interindusztriális esetében, hiszen az utóbbi helyzetben a termelési tényezőknek el kell hagyni a komparatív hátrányos szektorokat, és más ágazatokban kell hasznosulniuk, míg az előbbi esetben az igazodás csak ágazaton belül történik: ekkor a termelési tényezők konverziója is kevésbé költséges.

Begstrand (1990) modellje ${ }^{20}$ azért érdemel feltétlenül említést, mert a gravitációs egyenletre ${ }^{21}$ építve magyarázza a jövedelem, a tényezőellátottság és az ágazaton belüli áramlások arányát a teljes kereskedelemben.

Markusen és Venables (2000) a standard Helpman-Krugman modellt fejlesztik tovább, beépítve a szállítási költségeket és lehetővé téve a multinacionális vállalatok modellbeli működését a két országban. Rámutatnak, hogy nem csak az ágazaton belüli kereskedelem nagysága függ össze pozitív módon a két ország hasonlóságával, hanem a multinacionális vállalatok aktivitását is elősegíti a két ország abszolút és relatív tényezőellátottságának hasonlósága ${ }^{22}$.

\footnotetext{
18 ti. növekvő skálahozadék, horizontális termékdifferenciáció, monopolisztikus verseny

${ }^{19}$ Minimum efficient scale: egy vállalatnak az a mérete, amely mellett minimális a hosszú távú átlagköltség

20 Szoros elözménye Bergstrand (1989)

${ }^{21}$ A nemzetközi kereskedelem gravitációs modelljéről szóló, tartalmas, nem technikai jellegü összefoglalást találhatunk az IMF (2002) tanulmányának 122-123. oldalán (Box 3.3)

${ }^{22}$ Horizontális IIT-ről és FDI-ről van szó!
} 
A CHOS-modellt alapul véve Schmitt és Yu (2001) olyan modellt állít fel, amelyben szerepet kapnak a nemkompetitív (nontraded) javak is ${ }^{23}$, azáltal, hogy feltételezik, hogy a különböző cégek exportja eltérő nagyságú fix költségekkel jár. Fontos eredménye elméletüknek, hogy erős kapcsolatot tudnak kimutatni a skálahozadék szintje és a kereskedelem volumene között, amely a technológiai fejlődést középpontba állító magyarázata a világkereskedelem világtermelésnél megfigyelt nagyobb növekedési ütemének.

A HIIT vizsgálatában a monopolisztikus verseny feltételezés mellett már a korai időktől kezdve megjelennek a mainstreamnek mondható CHOS-elméletben szintetizálódó teóriáktól eltérő kiindulópontra helyezkedő teóriák is.

Brander (1981), illetve Brander és Krugman (1983) megteremti az ún. viszonos dömping modelljét, amelyben két, a saját országában monopol helyzetben lévő, homogén termékeket előállító vállalat a profitmaximalizálás érdekében a belföldinél alacsonyabb árakkal megjelenik a partnerország piacán is, ezzel nyilvánvalóan intraindusztriális áramlásokat generálva ${ }^{24}$. Ez a modell az utóbbi időkig viszonylag kevés figyelmet kapott az IIT-vel kapcsolatos elméleti és empirikus irodalomban - sokkal nagyobbat a dömpingre vonatkozóban - ennek ellenére azért vannak jeles folytatásai. Ezek közül is kiemelkedik Venables (1985), Weinstein (1992), Bernhofen (1999), Feenstra, Markusen és Rose (2001) ${ }^{25}$ munkája. Bernhofen (2001) a reciprok dömping tézist általánosítja, a homogén javak mellett a differenciált termékekre is alkalmazva.

Eaton és Kierzkowski (1984) modelljének szintén az a sajátossága, hogy a „fősodortól" eltérő, oligopolisztikus iparági szerkezetben mutatják ki, hogy sor kerülhet ágazaton belüli kereskedelemre ${ }^{26}$, azonban mint Greenaway, Hine és Milner (1995:1507) megjegyzi, ez a modell inkább a kivételek sorát erősíti, mert a HIIT esetében a monopolisztikus versenyre épülő teóriák jelentik a domináns paradigmát.

Ennek a dominanciának próbálnak kihívást nyújtani azok az elméletek, amelyek azt demonstrálják, hogy az iparágon belüli kereskedelem jól magyarázható a HOS modell keretein belül is. Az irányvonal legjelesebb képviselője Davis (1995), aki rámutat arra, hogy a CHOS-elmélet figyelmen kívül hagyja, hogy Észak országai között is jelentős különbségek vannak a termelékenységben. Davis bebizonyítja, hogy HIIT-re sor kerülhet állandó skálahozadék és tökéletes verseny körülményei között is. Modelljében két ország három terméket állít elő, melyek közül kettő ugyanahhoz, a relatíve tőkeigényesebb ágazathoz tartozik, és ugyanolyan tényezőfelhasználással termelik őket. A két utóbbi termék

\footnotetext{
${ }^{23}$ Korábban nemkompetitív termékeket is tartalmazó modellt Venables (1994) publikált: monopolisztikus szerkezetü ágazatban az exportáló és nem exportáló cégek közötti aszimmetriával.

${ }^{24}$ A profitmaximalizáló cégek azon a ponton müködnek, ahol érzékelt határbevételük megegyezik a határköltségükkel. Az érzékelt határbevétel két tényezőből tevődik össze, az egyik a bevétel amely egy újabb egység értékesítéséből származik, a másik pedig ugyanennek a többletértékesítésnek az árbevételt csökkentő hatásából. Azért hajlandó a cég a külpiacon a belföldi árnál olcsóbban (a határköltségnél természetesen drágábban) értékesíteni, mert az árbevételt csökkentő hatás itt számára csak kisebb mértékben jelentkezik.

${ }^{25}$ A szerzők a nemzetközi kereskedelem ún. gravitációs egyenletét vizsgálják differenciált és homogén termékek esetén, tehát e tanulmány nem sorolható kizárólagosan ehhez a területhez.

${ }^{26}$ A piaci egyensúly egy szekvenciális játék eredményeként alakul ki, ahol a cégek nem egyszerre döntenek a piacra lépésről, a gyártott termékváltozatról és az árról. Két azonos gazdaságot feltételeznek, mindkettőben két fogyasztói szegmentummal, amelyek különböznek az ideális termékváltozatra vonatkozó preferenciáikat illetően. A nemzetközi kereskedelem olyan szakosodáshoz vezet, hogy mindkét piacon csak egy-egy termelö lesz jelen egy-egy ideális változatot eloállitva. Ertelemszerüen ez intraindusztriális kereskedelmet eredményez. Kimutatják, hogy a kereskedelem megindulása utáni helyzet lehet Pareto-i értelemben kedvezőtlenebb, mint az autarchia, illetve azt is, hogy a kereskedelem akár csökkentheti is az elérhető termékváltozatok számát.
} 


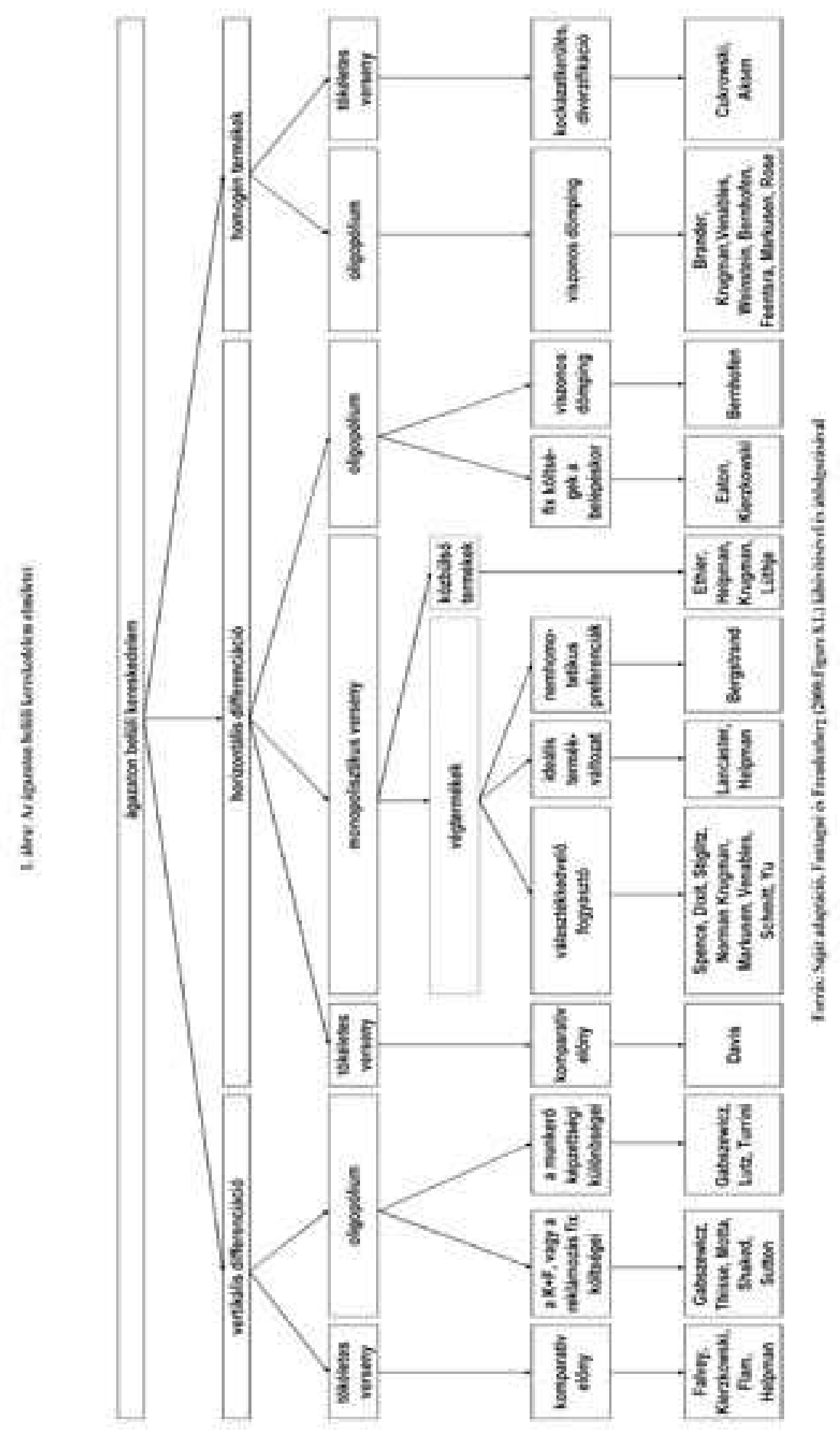


közül az egyik előállításában technológiai különbségek léteznek, aminek köszönhetően csak az egyik országban fogják azt elóállítani. Mivel a termék iránt mindkét országban létezik kereslet, a HOV-keretrendszerben is elöállhat az ágazaton belüli kereskedelem, ha a partnerország az ágazat másik termékét exportálja.

Cukrowski és Aksen (2003) modellje demonstrálja, hogy homogén termékekkel való kereskedelemre is sor kerülhet tökéletesen kompetitív iparágak feltételezése mellett, ha a kockázatkerülő cég a keresletben (az árakban) rejlő bizonytalanságot úgy próbálja meg kivédeni, hogy diverzifikálja piacait. Ha a fuvarozási költségek elég alacsonyak, akkor ez ágazaton belüli kereskedelemhez vezet akár minden szempontból hasonló országok között is.

\section{Vertikális ágazaton belüli kereskedelem}

A vertikális intraindusztriális kereskedelem (VIIT) esetében a termékváltozatok között minőségbeli különbségek vannak. Az empirikus kutatások kimutatták, hogy az ágazaton belüli kereskedelem döntő része ilyen típusú. Egyes szerzők Grubel és Lloyd (1975) definíciójára alapozva ${ }^{27}$ a VIIT fogalmához sorolják azt, amikor egy iparág végterméket exportál és a végtermék előállításához szükséges komponenseket importál. Mások, a többség - pl. Fontagné és Freudenberg (1997) - kizárják ezt a típust az ágazaton belüli kereskedelem fogalmából.

Falvey (1981), illetve Falvey és Kierzkowski (1987) úttörő elmélete a komparatív elönyökön alapszik. $2^{\star} 2^{\star} 2$-es megközelítésükben a vállalatok úgy viselkednek, mintha tökéletesen versenyzők lennének, miközben egy homogén és egy vertikálisan differenciált terméket gyártanak. A gazdaságban két termelési tényező létezik, munka és tőke. A termelésben felhasznált munka mennyisége és a termékminőség között nincs öszszefüggés, azonban a tőkeintenzitás növekedése jobb minőségü terméket eredményez. A tőke iparágspecifikus, azaz az ágazat cégei között szabadon mozog, azonban az iparágak között nem. A fogyasztók számára a differenciált javak nem tökéletes helyettesítők, szigorúan azt preferálják, amely a legjobb minőséggel rendelkezik.

Falvey és Kierzkowski (1987) modelljében a kereslet az adott minőség relatív ára és a fogyasztó jövedelme alapján határozódik meg, azaz a magasabb jövedelemmel rendelkező fogyasztók a jobb minőségű termékeket vásárolják.

A modell alapján Falvey és Kierzkowski (1987) arra a következtetésre jut, hogy a kereskedelem szerkezete erőteljesösszefüggést mutat az országok relatív tényezőellátottságával, a tőkében viszonylag gazdagabb ország a jobb minőségü termékekre, a másik az alacsonyabb minőségü javakra fog specializálódni, illetve, hogy a VIIT súlya a bilaterális kereskedelemben annál nagyobb lesz, minél jelentősebbek az ellátottságbeli különbségek ${ }^{28}$, és minél nagyobbak a piacaik. A két kulcsfontosságú tanulmányt összevetve elmondható, hogy a kínálati oldalt tekintve közeli rokonságban állnak, a jelentösebb különbségek a keresleti

\footnotetext{
${ }^{27}$ a vertikális intraindusztriális specializáció különböző formákat ölthet, magában foglalhatja azt a típusú cserét is, amikor ugyanaz az iparág végterméket cserél köztes termékre

${ }^{28}$ Feltételezve, hogy a relatív tőkellátottság növekedése visszatükröződik az egy före eső jövedelmekben.
} 
oldal megfogalmazásában vannak, melynek részletes kidolgozására a későbbi tanulmányban kerül sor. ${ }^{29}$

Míg Falveynál és Kierzkowskinál a termelési tényezők közül a tőkének jutott a föszerep Flam és Helpman (1987) - akik a fentiekhez igen hasonló következtetéseket vonnak le - a munkának tulajdonítanak kiemelkedő jelentőséget, azt egyedüli termelési tényezőként figyelembe véve. Ennek megfelelően a vertikális differenciáció itt nem a tényezőellátottság, hanem a technológia különbözőségeiből adódik, azaz a kínálati oldalhoz Ricardo-i alapokon közelítenek. Flam és Helpman modelljében az exogén technológiai fejlődés hatására magasabb minőségü termékek jelennek meg és néhány alacsonyabb minőségű gyártását abbahagyják. Az ágazaton belüli kereskedelmet itt is ugyanaz a jelenség - ti. a két ország jövedelemeloszlásában meglévő átfedés - okozza ${ }^{30}$.

Közös pontot jelent az eddig ismertetett VIIT-modellekben az is, hogy mindegyikben szerepet kap egy homogén termék is, amelynek eloóllításához kizárólag munkát használnak fel, amelyre mindkét országban van kereslet, és amelyet Dél állít elő olcsón a technológiai különbségeknek köszönhetően. A differenciálatlan termék jelenléte amellett, hogy segít magyarázni a kereskedelem szerkezetét, lehetővé teszi az inter- és intraindusztriális kereskedelem együttes kezelését.

Összességében tehát az országok a kínálati oldalon relatív tényezőellátottságuk és/ vagy technológiai előnyük-hátrányuk függvényében különböző minőségü, vertikálisan differenciált termékek előállítására szakosodnak, míg az eltérő termékváltozatok iránti keresletük elsősorban jövedelmi szintjüktől és jövedelemeloszlásuktól függ.

Stokey (1991) megközelítése, bár explicit módon nem vonatkozik az ágazaton belüli kereskedelemre, mégis említésre érdemes, hiszen kiterjeszthető a VIIT-re is ${ }^{31}$. Sajátossága, hogy a vertikális differenciáció a fogyasztók változatosság iránti vonzalmán alapszik. Míg Flamnél és Helpmannál a fogyasztó a vertikális spektrumból csak egyetlenegy terméket választhat - a magasabb (alacsonyabb) jövedelmű a jobb (rosszabb) minőségüt Stokeynál többet is ${ }^{32}$. Így abban az esetben is létrejöhet iparágon belüli kereskedelem, ha a két országban nincs a jövedelemeloszlásban átfedés. Más szavakkal úgy is lehet a fentieket magyarázni, hogy míg az előbbi modellben a két ország keresletében meglévő átfedéshez így a VIIT-hez a jövedelemstruktúra, addig utóbbiban a fogyasztók változatosság iránti igénye vezet.

${ }^{29}$ Minden fogyasztóról feltételezzük, hogy egyetlen - adott relatív termékárak mellett kizárólag a jövedelme által meghatározott - termékváltozat iránt mutat keresletet. Mivel az összjövedelem eloszlása a fogyasztók között nem egyenletes, minden időpillanatban különböző termékváltozatok iránt jelentkezik kereslet.

30 Leegyszerüsítve: Északon is élnek szegény és Délen is élnek gazdag emberek.

31 "A Flam-Helpman modell lehetőséget ad arra is, hogy különbséget tegyünk inter- és intraindusztriális kereskedelem között. A fenti modell (ti. Stokey-é - E. L.) ezt nem teszi lehetővé, azonban könnyedén módosítható úgy, hogy ez is lehetővé váljon. Egyszerüen tekintsünk úgy a javak kontinuumára, mint egy szektorra vagy iparágra, és adjunk ehhez egy homogén jószágot vagy egy másik differenciált termékekből álló szektort." (Stokey 1991:79)

${ }^{32}$ Meg kell jegyezni, bár nem tartozik szorosan a témához, hogy az Észak és Dél közötti kereskedelemben a minőségi különbségek mint a vertikális differenciáció alapja csak egy a lehetséges megközelítések közül. Matsuyamánál (2000) például a javakat a háztartások prioritásuk szerint indexelik, és a magasabb indexszel rendelkező termékek a jövedelem növekedésével kerülnek be a fogyasztói kosárba. Délnek az alacsonyabb indexü, alacsonyabb jövedelemrugalmasságú termékek előállításában van komparativ előnye. A modellben Észak és Dél termékei inkább kiegészítik egymást a fogyasztásban, mintsem helyettesítők, tehát elsősorban az ágazatok közötti kereskedelem Ricardo-i alapú magyarázatával van dolgunk. 
Ahogyan azt a horizontális intraindusztriális áramlások esetében láttuk, a modellek a vertikális ágazaton belüli kereskedelem esetében sem kizárólag egyetlen piaci szerkezetre szorítkoznak. Itt is viszonylag korán megjelentek az oligopóliumon alapuló elméletek.

Gabszewicz és szerzőtársainak (1981) VIIT modelljében a nemzetközi kereskedelemnek köszönhetően a rivális termelők közötti verseny addig csökkenti a jobb minőségű termékváltozatok árát, amíg néhány rosszabb minőségű termék és termelője kiszorul a piacról. Az elmélet néhány korlátozó feltételének ${ }^{33}$ feloldására a későbbiekben került sor.

Shaked és Sutton (1984) modelljében a vertikális ágazaton belüli kereskedelemre a $\mathrm{K}+\mathrm{F}$ fix költségei ${ }^{34}$ nyújtanak magyarázatot. Modelljükben - a korábbiakhoz hasonlóan - a fogyasztók jövedelmük függvényében a jobb minőségü terméket preferálják ${ }^{35}$, amely minőség itt a kutatás-fejlesztés függvénye. A K+F tevékenység a fix költségekben jelenik meg. Az elmélet növekvő skálahozadék és oligopol piaci szerkezet mellett ad magyarázatot a vertikális intraindusztriális kereskedelemre. Az egyensúlyhoz, akárcsak az EatonKierzkowski (1984) modellnél, egy többlépcsős játék vezet, amelyben a cégeknek dönteniük kell a belépésről, a mennyiségről és az árról. Mivel az átlagos változó költség csak lassan emelkedik a minőséggel, a cégek száma a piacon kötött. Itt is a magasabb (alacsonyabb) jövedelmű ország a jobb (rosszabb) minőségű termék előállítására specializálódik. Kimutatják, hogy a külkereskedelem, annak ellenére, hogy nem feltétlenül növeli az elérhető termékváltozatok számát, jólétnövelő hatással járhat együtt. Azáltal azonban, hogy a jobb minőségű termékek kiszorítják a rosszabbak egy részét, abban az országban, amelyben utóbbiakat gyártották, munkanélküliséghez vezethet, és ha az alacsonyabb árak ezt nem kompenzálják, negatív jóléti hatással is járhat.

Motta (1992) a fenti modellt úgy dolgozza át, hogy egyértelmüen megállapíthatólegyen megfelelő feltételrendszer mellett, hogy az országok veszítenek-e vagy nyernek a kereskedelemmel, illetve melyik ország lesz nyertes vagy vesztes. Egy másik munkájában (1994) a közvetlen külföldi tőkebefektetés és az IIT között pozitív kapcsolatra mutat rá.

Lutzés Turrini, illetve Gabszewiczés Turrini (2000) a munkaerő képzettségi különbségeivel magyarázzák a vertikális specializációt. Haucap, Weyés Barmbold (2000) esetében a VIIT a termékminőséggel kapcsolatos információs aszimmetriákból adódik: a fogyasztók a minőségre a származási országból következtetnek.

Összességében itt is elmondható, hogy változatos elméletekkel állunk szemben, amelyek különböző piaci szerkezetek mellett keresik a magyarázatot a vertikális ágazaton belüli kereskedelemre.

A horizontális esetben azt a megállapítást tehettük, hogy a monopolisztikus versenyre építő modellek jelentik az elméletek fó áramlatát. „Néhány kutató amellett érvel, hogy nincs szükség a termékdifferenciációtés növekvő skálahozadékot feltételező modern nemzetközi közgazdaságtani elméletre a világkereskedelem legfontosabb jellegzetességeinek,

33 Speciális, a szerzők által "lineáris"-nak aposztrofált hasznosságfüggvény, egyenletes jövedelemeloszlás, a fogyasztók egyező izlésvilága, a gyártott termék minőségének a cég számára exogén volta.

${ }^{34}$ Ezek a modellben elveszett költségekként (sunk cost) szerepelnek. Ilyen költségeket jelenthet a reklámozás is (Shaked és Sutton (1987), Sutton (1991), Motta (1993).

${ }^{35}$ A tárgykörbe tartozó modellek jelentős része a Gabszewicz és Thisse (1979), illetve a Shaked és Sutton (1982) által kifejlesztett vertikális differenciációs alapokra épít: a fogyasztók preferenciái megegyeznek, de a jövedelmi differenciáknak köszönhetően különbségek alakulnak ki a vásárolt minöségben. A tipikus, duopolisztikus modellben két cég, melyek fix költségei a minőségtől függnek, kínál különböző termékváltozatokat ugyanazon a piacon. Mivel a megkülönböztetés csökkenti a helyettesithetőséget és az árversenyt, az egyensúlyi helyzetben még az azonos költségszerkezettel bíró cégek is különböző termékváltozatokat fognak elöállítani. 
az ágazaton belüli kereskedelem jelenségének, a gazdasági növekedés és a kereskedelem volumenének növekedése közötti kapcsolat, az észak-észak és az észak-dél relációjú kereskedelmi volumenek közöttikülönbség magyarázatához... hiszen minden lehetséges jelenségre találunk egy olyan szerkezetű, homogén termékeket feltételező Heckscher-Ohlin-i modellt, amelyben ezek a jelenségek ugyancsak elöállnak. Ez természetesen jogos és intellektuális szempontból érdekes vita. Véleményem szerint azonban a termékdifferenciáció annyira általános jelenség, hogy nehéz megérteni, hogy miért van egyáltalán arra szükség, hogy igazolni kelljen jelenlétét a közgazdaságtani modellekben...

Úgy tisztességes fogalmazni, hogy a létező modellek közül egyik sem remekel az adatok magyarázatában. A termékdifferenciáció bevezetésével azonban az elméletek és az adatok illeszkedése javul... és ezek a modellek magukban hordozzák a még jobb magyarázatok lehetőségét.

Mára gazdag tárházával rendelkezünk azoknak az elméleteknek, amelyek a világkereskedelem kulcsfontosságú meghatározóiként emelik ki a növekvő skálahozadékot, termékdifferenciációt és a tényezőösszetétel különbségeit. Ezek az elemek összekapcsolva a specializáció irányának, a kereskedelem volumenének, tényezőtartalmának, a régiók közötti kereskedelem szerkezetének szignifikáns részét magyarázzák.

Az elmúlt 20 esztendő minden kutatási igyekezetének ellenére a magyarázatok még mindig hiányosak, ami részben annak köszönhetö, hogy a világkereskedelem természete gyorsan változik... Több technológiai orientációjú elméletre és a dinamika hangsúlyának növekedésére van szükség, hogy megértsük a fejleményeket. Az 1990-es években születtek ilyen elméletek és ezek kétségkívül hatással lesznek a jövőbeli empirikus kutatásokra.” (Helpman 1999:141-142).

A vertikális IIT esetében azt mondhatjuk, hogy föként a tradicionális elméleteken nyugvó teóriák dominálnak, de az oligopolisztikus szerkezetet alapul vevő modellek relevanciája és plauzibilitása is jelentős. Az utóbbi csoportba tartozó elméletek alkalmasabbak arra, hogy elöre jelezzék, mely termékváltozatokat mely országok fogják gyártani. A témához az ökonometriai vizsgálatok ismertétese során hamarosan visszatérünk, azonban az már most is nyilvánvaló, hogy a HIIT-t és VIIT-t meghatározó tényezőket illetően a modellek alapján jelentős különbségekre számíthatunk.

\section{Az ágazaton belüli kereskedelmet meghatározó tényezők}

Az ágazaton belüli kereskedelem meghatározóit az elmúlt évtizedekben számos ökonometriai tanulmány kísérelte meg leírni. A mai napig elmondható, hogy e kutatási területen koránt sincs összhang, bár jól láthatóan két csoportba lehet sorolni azokat a változókat, amelyek hatásának vizsgálata - nyilvánvalóan a miatt, hogy az elméletek ezeket sugallják a legnagyobb népszerüségnek örvendett: ez a két csoport az ország- és az ágazatspecifikus faktorok csoportja ${ }^{36}$. 


\section{Országspecifikus tényezők}

A gazdaság(ok) fejlettsége: növekedésével javul az ország képessége a progresszív, differenciált termékek elöállítására, illetve a jólét növekedésével a fogyasztók ilyen termékek iránti kereslete is emelkedik.

A két ország hasonlósága: bilaterális kereskedelmükben az ágazaton belüli áramlások annál intenzívebbek, minél hasonlóbb fejlettségi színvonaluk. Meg kell jegyezni, hogy többek között Brainard (1993), Horstmann és Markusen (1987, 1992), illetve Markusen és Venables $(1998,2000)$ multinacionális vállalati modelljei azt sugallják, hogy a hasonlóság növekedésével elöször nő, majd csökken az IIT, amelyet utóbbi fázisban a multinacionális vállalatok helyi termelése vált fel ${ }^{37}$. Ez a kapcsolat azonban korántsem teljesen egyértelmü.

A piac mérete: akár a Dixit-Stiglitz, akár a Lancaster-féle fogyasztói modellre építünk, nagyobb piacok esetén jobb lehetőség nyílik a termékdifferenciációra, illetve a méretgazdaságosság kihasználására.

Mindhárom eddig említett jellemzőről megállapítható, hogy amennyiben külön-külön vizsgáljuk hatásukat a horizontális és a vertikális IIT-re, akkor elöjelüket tekintve eltérő következtetéseket vonhatunk le az elméleti modellekből. Az előbbiekben jelzettekhez képest ugyanis a gazdasági fejlettségben meglévő különbségek a tényezőellátottság-beli különbségeket is tükrözik: a tőkével relatíve jobban ellátott ország - legyen szó akár fizikai, akár humántőkéről - fogja ugyanis előállítani a vertikálisan differenciált termékek közül a jobb minőségűt, míg fejletlenebb partnere az alacsonyabb minőségüt: ennek megfelelően tehát, míg a hasonlóság ezekben a jellemzőkben a horizontális, a különbözőség a vertikális ágazaton belüli kereskedelemnek kedvez.

A földrajzi közelség: több szempontból is fontos. Minél közelebb vannak a kereskedő partnerek, annál alacsonyabbak a szállítási költségek, következésképpen annál magasabb lehet, minden egyéb tényező változatlansága mellett, a bilaterális kereskedelem. A távolság „elbátortalanítóbb” hatással lehet az ágazaton belüli, mint az ágazatok közötti kereskedelemre, mivel feltételezhetö, hogy a differenciált termékeknek több hazai helyettesítője van, mint a homogéneknek. Balassa és Bauwens (1987:927) szerint a differenciált termékek kereskedelmében az információ költségei nagyobbak, mint homogén termékek esetében, és nőneka távolsággal.Aközelségemellettjelenthethasonlóerőforrás-(tényező)ellátottságot, ízlésvilágot, kultúrát, amelyek mind-mind az iparágon belül áramlásokat erősítik.

A protekcionizmus szintje: evidens, hogy a kereskedelem korlátozása az iparágon belüli áramlásokra is kedvezőtlen hatással van.

A gazdasági integráció: akár gyengébb, akár szorosabb a két ország közötti integrációs kapcsolat, a kereskedelmi korlátok lebontása a tranzakciós költségeket csökkenti. Azt is megfigyelhetjük, hogy ilyen viszony kialakítására legtöbbször kulturális szempontból hasonló országok között kerül sor.

Utóbbi három tényezőt tekintve az elméletek alapján nem várunk különböző hatást a vertikális és horizontális IIT-t illetően.

${ }^{37}$ Ld. pl. Markusen (1995:180) 


\section{Ágazatspecifikus tényezök}

A termékdifferenciáció: ahogy már a korábbiakban is említettük, növekedésével a HIIT is valószínűleg nőni fog. Nagyságára a konkrét mérőszámokon kívül az iparági K+F és reklámkiadások nagyságából is következtetni szoktak, hiszen az új termékváltozatokat ki kell fejleszteni és piacra kell vinni. Mivel a VIIT esetében ugyannak a terméknek a különböző minőségü változataival való kereskedelemről van szó, a differenciáció ennek valószínüleg nem kedvez.

A skálahozadék: a legtöbb HIIT-vel kapcsolatos elmélet központi eleme a növekvő skálahozadék, amely nagyobb IIT-vel jár. Kulcsmérőszám a hatékony minimális méret is: minél alacsonyabb, annál több vállalat tud belépni az iparágba, annál magasabb a termékváltozatok száma, következésképpen a HIIT is. Láthatjuk tehát, hogy a kép nem egyértelmü. Gullstrand (2002) inverz U-alakú kapcsolatként írja le a skálahozadék és az IIT öszszefüggését: a növekvő skálahozadéknak csak addig lesz pozitív hatása az iparágon belüli kereskedelemre, amíg nem jár korlátozó hatással az iparágon belül müködő cégek számát tekintve, illetve amíg nem eredményezi a termékek standardizációját.

A piacszerkezet: láthattuk az elméleti modellek tanulmányozása során, hogy az IITvel kapcsolatos teóriák rendkívül változatosak abban a tekintetben, hogy milyen piaci struktúra feltételezésére épülnek. Megállapítottuk, hogy míg a horizontális IIT esetében leginkább a monopolisztikus versenyre építő modellek képezik a mainstream irányzatot, addig a VIIT esetében a tökéletes versenyre építő modellek plauzibilitása erősebb, ennek megfelelően az előző, skálahozadék változó által a VIIT-re gyakorolt hatás is ellenkező elöjelü, mint a HIIT esetében.

A terméknek az életciklusban betöltött helye: ahogy a termék az életciklusában elöre halad, úgy változik az elérhető termékváltozatok száma is. A bevezetés és a hanyatlás időszakában ezek száma alacsonyabb, a növekedés és az érettség időszakában, a piaci verseny intenzitása és a differenciálódó vagy koncentrálódó célcsoportképzési stratégia miatt tendenciaszerüen magasabb.

A multinacionális vállalatok szerepe: a multinacionális vállalatok jelenlétét a legtöbb kutatás hipotetikusan az ágazaton belüli áramlások ösztönzőjeként kezeli, arra alapozva, hogy a vállalaton belüli kereskedelem, amely döntően a nemzetközi termelésmegosztást tükrözi, vélhetően ugyanazon az iparágon belüli kereskedelmi mozgásokat indukál. A gyakran többtermékes multinacionális vállalatok nagyobb specializációval, nagyobb IITvel járnak. Az összefüggés megítélésem szerint nem ennyire egyértelmű: itt elsősorban arra a széles körben kutatott dilemmára kell utalnunk, amely arra a kérdésre keresi a választ, hogy a közvetlen külföldi tőkebefektetések (FDI) vajon kiegészítői, ösztönzői-e vagy inkább helyettesítői-e a nemzetközi kereskedelemnek. A vertikális FDI vélhetően - azáltal, hogy multinacionális termelési lánc jön létre - elsősorban az interindusztriális folyamatokat ösztönzi, hiszen a fragmentáció a termelékenységi, relatív tényezőellátottsági különbségeken alapszik. A horizontális FDI esetében a leányvállalati termelés kiválthatja a célországba irányuló exportot, de persze ösztönözheti - föként az anya- és a leányvállalat között - a szolgáltatáskereskedelmet vagy a differenciált végtermékek kétirányú forgalmát. 


\section{Következtetések az empirikus ökonometriai vizsgálatok fényében}

Foglaljuk össze röviden az ágazaton belüli kereskedelem okait kutató empirikus vizsgálatok eredményeit annak a törekvésnek megfelelöen, hogy az áttekintésbe a területet legjobban reprezentáló, legtöbbet hivatkozott tanulmányok - tehát, amelyek megtermékenyitó hatással voltak a későbbi kutatásokra - mellett beemeljünk néhány kevésbé ismertet is, hogy a világ minél több régiója, illetve az észak-észak áramlások mellett az észak-dél áramlások is szerepet kaphassanak a leírásban.

Közös ezekben a vizsgálatokban, hogy gyakran eltérö elméleti alapokról kiindulva az iparágon belüli kereskedelem valamely indexe és az ország- és/vagy iparágspecifikus tényezők közöttikapcsolatot keresik, leggyakrabban többváltozós regressziós egyenletbecslésével és analízisével. Az eredményeket, illetve az értelmezésükhöz szükséges tudnivalókat a következő táblák mutatják be. ${ }^{38}$

1/1. tábla: A meghatározó tényezők hatásának mérésére szolgáló változók az empirikus tanulmányokban

\begin{tabular}{|c|c|}
\hline Meghatározó tényező & Az ökonometriai vizsgálatban alkalmazott változók \\
\hline \multicolumn{2}{|l|}{ Országspecifikus tényezők } \\
\hline $\begin{array}{l}\text { 1. Gazdasági fejlettség (hason- } \\
\text { lóság és különbség) }\end{array}$ & $\begin{array}{l}\text { GDP/fö, GDP/fö különbség, a GDP-k különbsége átlagos K/L } \\
\text { arány, K/L arány (különbsége) a partnerhezviszonyítva,egyen- } \\
\text { lötlenségi index és annak egy före vetített értéke (Balassa), } \\
\text { munka/föld arány, a humántőkével való relatív ellátottság, a } \\
\text { jövedelem-eloszlás abszolút és relatív mutatói, a feldolgozó- } \\
\text { ipar részesedése az exportból, a bilaterális kereskedelmi mér- } \\
\text { leg egyenlege, valamint a következő pont mutatói is fontosak } \\
\text { lehetnek itt is }\end{array}$ \\
\hline 2. A piac mérete & $\begin{array}{l}\text { Az országok GDP-je, átlagos GDP/fó, azok összege, átlaga, a } \\
\text { relatív piacnagyság mutatója (Helpman) }\end{array}$ \\
\hline 3. A földrajzi távolság & $\begin{array}{l}\text { Határ dummy (0, ha nincs } 1 \text { ha van a két országnak közös hatá- } \\
\text { ra), a két ország (pl. fővárosa) közötti távolság }\end{array}$ \\
\hline 4. Gazdasági integráció & $\begin{array}{l}\text { Integrációs dummy }(0 \text {, ha nincs, } 1 \text {, ha van a két ország között), } \\
\text { a támogatás tényleges szintje (ERA) })^{39} \text {, a partnerországból szár- } \\
\text { mazó FDI }\end{array}$ \\
\hline 5. Protekcionizmus & $\begin{array}{l}\text { Átlagos vámszint, a vámok különbözősége, kereskedelmi ori- } \\
\text { entáció (Balassa) }\end{array}$ \\
\hline
\end{tabular}

38 Jelmagyarázat a táblákhoz: c: az országspecifikus tényezőket vizsgáló tanulmány, i: az iparág-specifikus tényezőket vizsgáló tanulmány, d: a HIIT-t és VIIT-t elkülönítve vizsgáló tanulmány, H: horizontális, V: vertikális, VIIThq: magas minőségü VIIT, VIITlq: alacsony minőségü VIIT, rHIIT=HIIT/IIT, rVIIThq=VIIThq/VIIT, prelib: a liberalizációt megelőző helyzet, postlib: a liberalizáció utáni helyzet.

Az ábrákban az áttekinthetőség kedvéért csak a 10\%-os szinten is szignifikáns kapcsolatokat jeleztem.

${ }^{39}$ Effective Rate of Assistance: annyiban különbözik az ERP (Effective Rate of Protection - a védelem tényleges szintje) mutatótól, amely a kereskedelmi korlátozások és intervenciók együttes hatását méri bizonyos tevékenységek termékei és forgalomképes alapanyagai hozzáadott értékéhez viszonyítva, hogy magában foglalja az ár jellegü piaci beavatkozásokat és a kormányzati kiadások hatásait is. (Guba 2000:116.) 


\begin{tabular}{|c|l|}
\hline Meghatározó tényező & Az ökonometriai vizsgálatban alkalmazott változók \\
\hline Ágazatspecifikus tényezők & $\begin{array}{l}\text { Horizontális és vertikális termékdifferenciáció, a termékkate- } \\
\text { góriák száma az iparágon belül, Hufbauer-index (1970), CEPII } \\
\text { differenciációs változó }{ }^{40}, \mathrm{~K}+\mathrm{F} \text { intenzitás, reklámozás, a nem- } \\
\text { termelésben dolgozó,szakképzett, technikai személyzet aránya, } \\
\text { az ágazat humántőke-intenzitása, a termelés fizikaitőke-inten- } \\
\text { zitása }\end{array}$ \\
\hline 6. Termékdifferenciáció & $\begin{array}{l}\text { Skálahozadék, hatékony minimális méret,a nagyvállalatokáltal } \\
\text { foglalkoztatottak aránya, a nagy cégek relatív termelékenysége, } \\
\text { átlagos vállalatméret }\end{array}$ \\
\hline 7. Skálahozadék & $\begin{array}{l}\text { A vállalatok száma az iparágon belül, a koncentráció aránya, a } \\
\text { profitráták szórása, amerikai piacrészesedés }\end{array}$ \\
\hline 8. Piacszerkezet & $\begin{array}{l}\text { Termékéletciklus: a termék életkora szorozva az ágazati szaba- } \\
\text { dalmak számával }\end{array}$ \\
\hline 9. Termékéletciklus & $\begin{array}{l}\text { A külföldi cégek részesedése az értékesítésben, az ágazati hoz- } \\
\text { záadott értékben, külföldi összeszerelés, vállalaton belüli keres- } \\
\text { kedelem }\end{array}$ \\
\hline 10. A multinacionális vállalatol \\
szerepe
\end{tabular}

A legfőbb megállapítások a következők lehetnek - tartózkodva attól, hogy megismételjük az ország- és ágazatspecifikus tényezők kifejtése során leírtakat:

Összességében elmondható, hogy az empirikus eredmények sokszínűsége és időnként jócskán ellentmondásos volta jól tükrözi az elméleti modellek vizsgálatánál tapasztalt változatosságot, megerősítve azt, hogy ma még nem rendelkezünk olyan teoretikus keretrendszerrel, amely kizárólagosságra törhetne az intraindusztriális kereskedelmi folyamatok magyarázatában, vannak azonban plauzibilisebbek és kevésbé plauzibilisek.

A kezdeti tapasztalatok azt mutatták, hogy az országspecifikus tényezők magyarázóereje és konzisztenciája jelentősen meghaladja az iparágspecifikus tényezőkét, utóbbiak ellentmondásos volta és érzékenysége az ökonometriai problémákra ${ }^{41}$ azonban jelentős mértékben csökkent a horizontális és vertikális ágazaton belüli kereskedelem szétválasztásával a vizsgálatokban. Ez utóbbi, bár triviálisnak tűnik, rendkívül fontos lépésnek tekinthető. Az elméletek szerint a horizontális és vertikális ágazaton belüli kereskedelem mögött meghúzódó tényezők eltérőek, tehát ezeket egymástól elválasztva a regressziós egyenletek magyarázó ereje várhatóan - és a tapasztalatok szerint ténylegesen is - jelentősen emelkedik, bár az iparágspecifikus tényezők esetében továbbra is jelentős inkonzisztenciával találkozhatunk: ennek magyarázatai vélhetőleg egyrészt a jelenségek mérésének problémáiból, másrészről az elméletek sokszínűségéből adódnak. Vannak perszeközös tényezők is: a fejlettség, a piacok nagysága, az integráció, a protekcionizmus alacsony szintje mind-mind kedvezően hatnak az IIT-re.

Ha elválasztjuk egymástól az ágazaton belüli kereskedelem horizontális és vertikális formáját, azt tapasztalhatjuk, hogy a HIIT magyarázatában nemcsak az elméletben sokkal népszerübb horizontális differenciáció, növekvő skálahozadék, monopolisztikus ver-

\footnotetext{
${ }^{40}$ Fontagné, Freudenberg és Péridy (1997)

${ }^{41}$ ld. pl. Torstensson (1996)
} 


\section{1/2. tábla: Az országspecifikus tényezőket vizsgáló kutatások}

\begin{tabular}{|c|c|c|c|c|c|c|}
\hline Vatoed & $\begin{array}{l}\text { Bularesa } \\
\text { (1906a) }\end{array}$ & $\begin{array}{l}\text { Batissa } \\
\text { (1066b) }\end{array}$ & $\begin{array}{c}\text { Melpmen } \\
\text { [108?] }\end{array}$ & $\begin{array}{c}\text { Bergstrand } \\
{[10 \mathrm{~s} 0]}\end{array}$ & $\begin{array}{c}\text { Hummis: } \\
\text { Levrschn (1995) }\end{array}$ & $\begin{array}{l}\text { Havolyston: } \\
\text { Kunzel (195?) }\end{array}$ \\
\hline rivea & 6 & 8 & 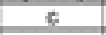 & 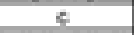 & 8 & 8 \\
\hline & & & & & & \\
\hline \multicolumn{7}{|l|}{ 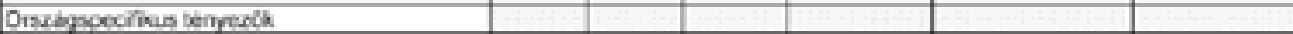 } \\
\hline A GCP $\rightarrow$ kilonksegs & & & & 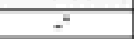 & & \\
\hline Az cratgok copho mutabjo & & & & & & * \\
\hline GDPAS künosisy & & & 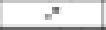 & $x^{*}$ & $a^{*}$ & \\
\hline Egyeniotionsegi index (Balassa) & & 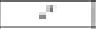 & & & & \\
\hline Egyendolendegess index (Balessa) & & $*^{*}$ & & & & \\
\hline 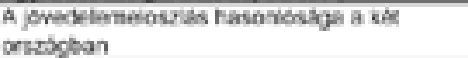 & & & & & $\therefore$ & \\
\hline \multicolumn{7}{|l|}{ A pertiner GIN indere } \\
\hline \multicolumn{7}{|l|}{ 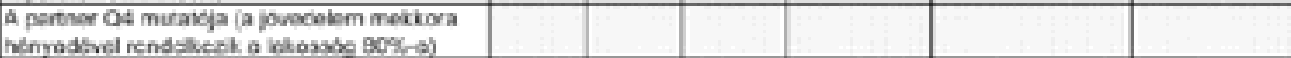 } \\
\hline átages $k$ / ataty & & & & $\Rightarrow$ & & \\
\hline \multicolumn{7}{|l|}{ 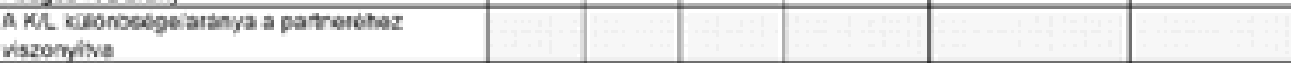 } \\
\hline Nonkwoid aring & & & & & $\AA^{*}$ & \\
\hline \multicolumn{7}{|l|}{ 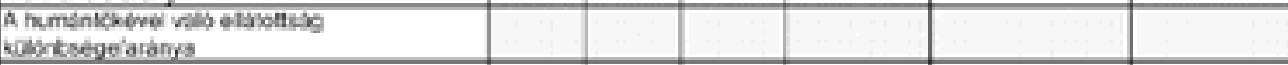 } \\
\hline \multicolumn{7}{|l|}{$\begin{array}{l}\text { Technoliogai eidmynabainy a pertnerrel } \\
\text { saemken }\end{array}$} \\
\hline \multicolumn{7}{|l|}{ A leimels humberimenclisa } \\
\hline 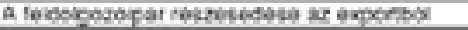 & & & & & & * \\
\hline Az encrbok GDFe & & & $(+h)^{2}$ & & & $t^{2}$ \\
\hline Az croviook aflagos GDP.je & $+^{*}$ & + & & $+^{2}$ & & \\
\hline \multicolumn{7}{|l|}{ A COP k cenzogs } \\
\hline Átagos CDPAS & $+*$ & $*$ & & & & \\
\hline 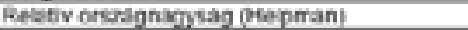 & & & $*$ & & & \\
\hline Thvoled & +4 & 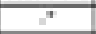 & & & ${ }^{*}$ & \\
\hline Ax cruvipok kozos haliva & +4 & $++^{*}$ & & $+^{*}$ & & \\
\hline$A_{2}$ crnelgok $k 6 z 00$ incegraso & & * & & & & * \\
\hline \multicolumn{7}{|l|}{ 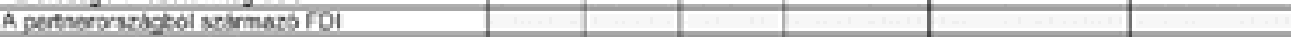 } \\
\hline Kelesked-Imi oriantiocio & $4^{*}$ & + & & & & $*$ \\
\hline Atagos vament & & & & $\therefore$ & & \\
\hline 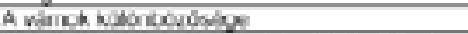 & & & & $\Sigma^{*}$ & & \\
\hline \multicolumn{7}{|l|}{ 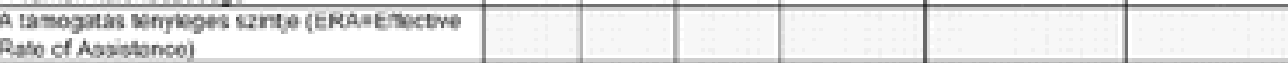 } \\
\hline 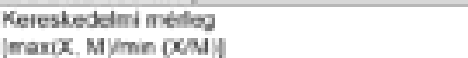 & & & & & & \\
\hline
\end{tabular}

Forrás: Andresen (2002), saját kiegészítésekkel

seny kaphatnak nagyobb hangsúlyt, hanem más piaci szerkezetek is ${ }^{42}$. A VIIT esetében elmondható, hogy magyarázatában a tradicionális elméletek - neo-HO és neo-Ricardo-i - játszanak nagyobb szerepet, azonban relevanciával bírnak a nem kompetitív piacot feltételező modellek is, valamint nagy szerepe van az országok jövedelemeloszlásában való átfedésnek is.

4) Az ágazaton belüli kereskedelemben a legtöbb viszonylatban a vertikális ágazaton belüli kereskedelem túlsúlyát vagy erőteljesebb dinamizmusát tapasztalhatjuk ${ }^{43}$ a horizontálissal szemben, amely a kereskedelmi liberalizációval együtt járó alkalmazkodási

42 Greenaway, Hine és Milner (1995) eredményei szerint a sok vállalatból álló piac feltételezéséhez jobban illeszkedik VIIT, mint a HIIT. Ezt más tanulmányok mint pl. Aturupane és szerzőtársai (1997), Celi (1999), Greenaway, Milner és Elliott (1999) stb. nem erősítik meg.

43 ld. pl. Greenaway és szerzőtársai (1994, 1995) az Egyesült Királyság bilaterális kereskedelmében, Fontagné, Freudenberg és Peridy (1997, 1998) az intra-EU kereskedelemben, Aturupane és szerzőtársai (1997) az EU-CEEC (közép-kelet-európai) viszonylatban, Hu és Ma (1999) Kína esetében stb. 


\section{1/3. tábla: Az ágazatspecifikus tényezőket vizsgáló kutatások}

\begin{tabular}{|c|c|c|c|c|}
\hline Valtozo & $\begin{array}{l}\text { Caves } \\
(1981)\end{array}$ & $\begin{array}{l}\text { Toh } \\
(1982)\end{array}$ & $\begin{array}{l}\text { Greenaway- } \\
\text { Milner (1994) }\end{array}$ & $\begin{array}{l}\text { Hughes } \\
\text { (1993) }\end{array}$ \\
\hline \multirow[t]{2}{*}{ Tipus } & 1 & 1 & 1 & 1 \\
\hline & & & & \\
\hline \multicolumn{5}{|l|}{ 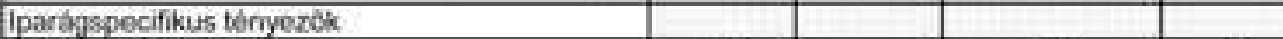 } \\
\hline Temekdiflerenciaço & + & & $+*$ & $+^{*}$ \\
\hline \multicolumn{5}{|l|}{ Vertikilis termekdifferencidcio } \\
\hline \multicolumn{5}{|l|}{ CEPII differenciaciós valtozo } \\
\hline Hufbauer index & & + & & \\
\hline Resdam-ertekesites arfany & & & $*^{*}$ & \\
\hline K+F kiadabsok & & & & $+^{*}$ \\
\hline \multicolumn{5}{|l|}{$\begin{array}{l}\text { A K }+F \text { szemelyzet aránya a foglalkoztatottakon } \\
\text { belul }\end{array}$} \\
\hline $\begin{array}{l}\text { A szakkelprett es technikai szemelyzet } \\
\text { reszosedose a foglalkoztatottakon bolut }\end{array}$ & & & & $(+i-)^{*}$ \\
\hline \multicolumn{5}{|l|}{ Az dgaza! humancoke intenzetasso } \\
\hline \multicolumn{5}{|l|}{ A gyalinoszzemelycet arinya } \\
\hline \multicolumn{5}{|l|}{ A termoles fizikaridke-infenzitassa } \\
\hline Skálahozadek (SE) & & & $\because$ & \\
\hline \multicolumn{5}{|l|}{$\mathrm{SE}^{2}$} \\
\hline \multicolumn{5}{|l|}{ Hatokony minimslis moret } \\
\hline \multicolumn{5}{|l|}{ A nagy cegek relativ sermelekenysege } \\
\hline \multicolumn{5}{|l|}{ Biagos vâlatatméret } \\
\hline \multicolumn{5}{|l|}{ A nagyvallobiatok dital foglalknztatottak arbinya } \\
\hline \multicolumn{5}{|l|}{ A peofitratak szórása } \\
\hline A koncentracio aranya & & $=$ & $\therefore$ & \\
\hline \multicolumn{5}{|l|}{ Amerikai (USA) piacreszesedes } \\
\hline \multicolumn{5}{|l|}{ A vállalabok száma az iparagon belul } \\
\hline Temákéletciōlus & & * & & \\
\hline Vallalaton belohi kereskedelem & +4 & & & \\
\hline \multicolumn{5}{|l|}{ Kalfoldi ósszeszereles } \\
\hline \multicolumn{5}{|c|}{$\begin{array}{l}\text { A kujoldi cégek részesedése az trtékesitesten } \\
\text { (FDI) }\end{array}$} \\
\hline \multicolumn{5}{|c|}{$\begin{array}{l}\text { A koitolid clgek részesedese a hozzdadott } \\
\text { entekben. entekesilesben (FDI) }\end{array}$} \\
\hline $\begin{array}{l}\text { A magas jovedelmu orszitgokikal folytatott } \\
\text { keseskedelem intenzitasa }\end{array}$ & & $*$ & & \\
\hline \multicolumn{5}{|l|}{ A Elagos fuvartávolsagy } \\
\hline Kulfoldi kozvetien befektetesek & $\therefore$ & & & \\
\hline \multicolumn{5}{|l|}{ Az export egységertétee } \\
\hline \multicolumn{5}{|l|}{ A vàtarifak eloszlasa } \\
\hline \multicolumn{5}{|l|}{$\begin{array}{l}\text { Az Ágazat fogyaszlónak valtozitiossigi, } \\
\text { diszperzios indexe }\end{array}$} \\
\hline Az àgazati szálilitasok entéke & & & & \\
\hline
\end{tabular}

Forrás: Andresen (2002) 
1/4. tábla: Az ország- és ágazatspecifikus tényezőket együttesen vizsgáló modellek: országspecifikus tényezők

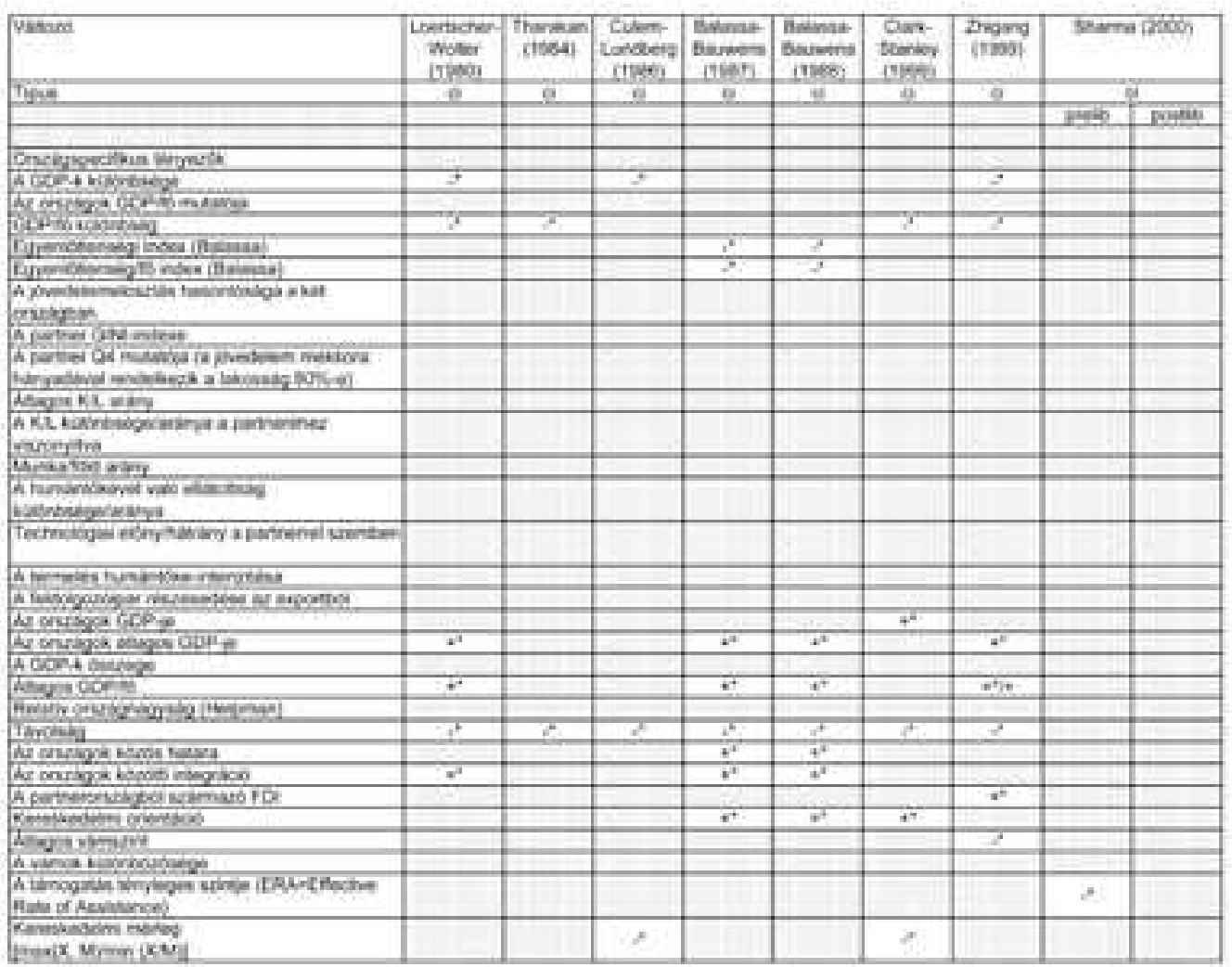

Forrás: Andresen (2002), saját kiegészitésekkel

költségekkel kapcsolatos optimizmust is csökkentette valamelyest, másrészről segít megmagyarázni az empirikus vizsgálatoknak azt a sajátosságát, hogy a vertikális és a totális ágazaton belüli kereskedelmet magyarázó tényezők nagyfokú hasonlóságát tapasztaljuk.

5) Az ökonometriai tanulmányok tanulsága szerint egy ország kereskedelmi szempontbólmegfigyelhetőspecializálódottságánakmértékefejlettségénekfüggvénye. A fejlett és az újonnan iparosodó országok tendenciaszerüen magasabb IIT-vel rendelkeznek, mint a fejlődőek. Az észak-dél kapcsolatokban is növekszik az ágazaton belül kereskedelem aránya, ami összekapcsolható a multinacionális vállalatok tevékenységével, a nemzetközi működőtőke-áramlással és a globális termelésmegosztás fejlődésével. ${ }^{44}$ Ebbőllevonhatjuk azt a következtetést, hogy az IIT szintje jó fokméröje a nemzetközi verseny- és alkalmazkodási képességnek. Azok között az országok között, amelyek bilaterális kereskedelmében magas az ágazaton belüli áruforgalom aránya, az integrációs megállapodások nagyobb sikerre számíthatnak; ez akkor is igaz lehet, ha maga a liberalizáció eredményezi ezt a magasabb szintet.

${ }^{44}$ Id. pl. Aturupane és szerzőtársai (1997), Clark és Stanley (1999) 
1/5. tábla: Az ország- és ágazatspecifikus tényezőket együttesen vizsgáló modellek: ágazatspecifikus tényezők

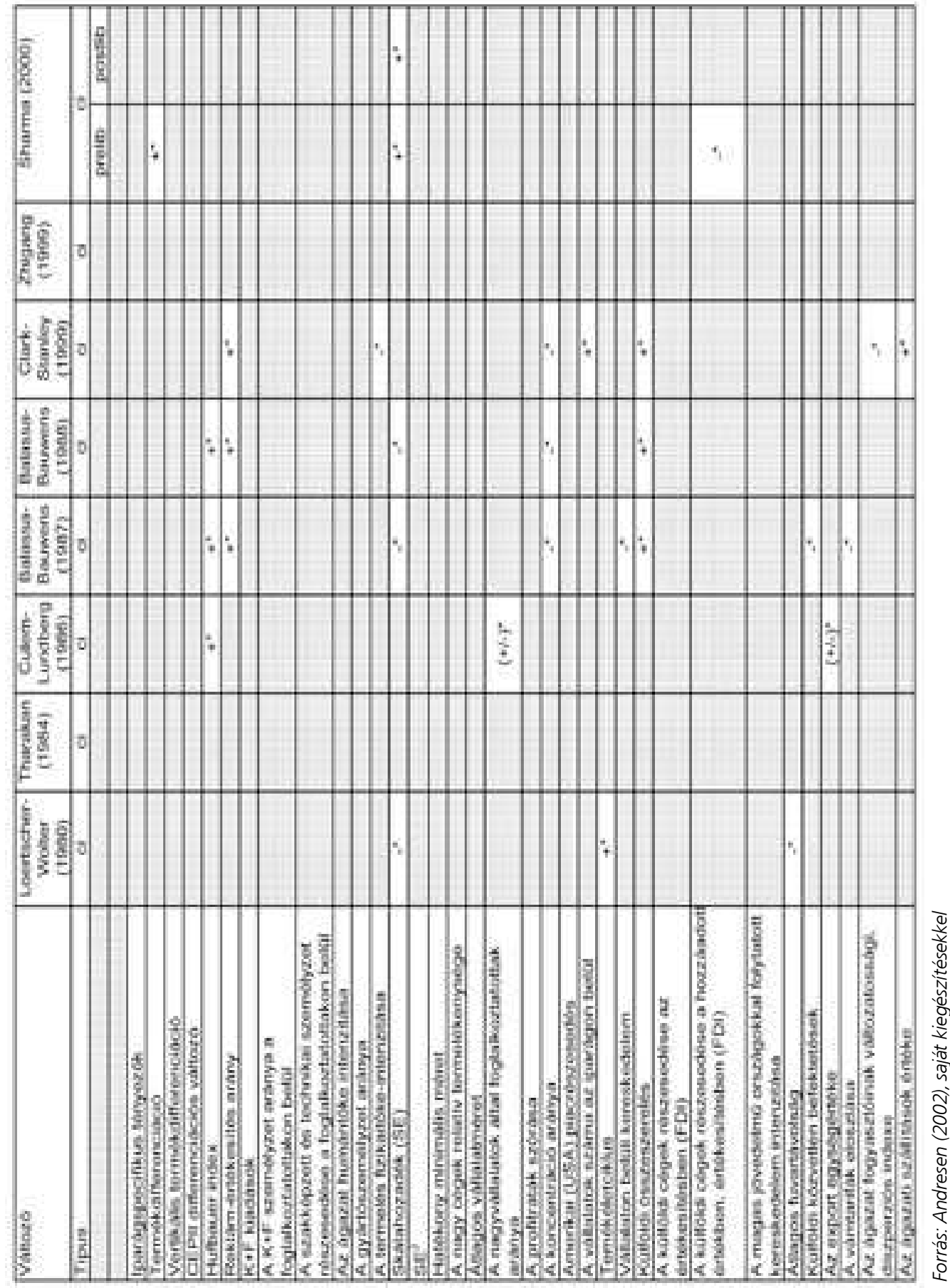


1/6a. tábla: A HIIT-t és VIIT-t elkülönítő vizsgálatok: országspecifikus tényezők

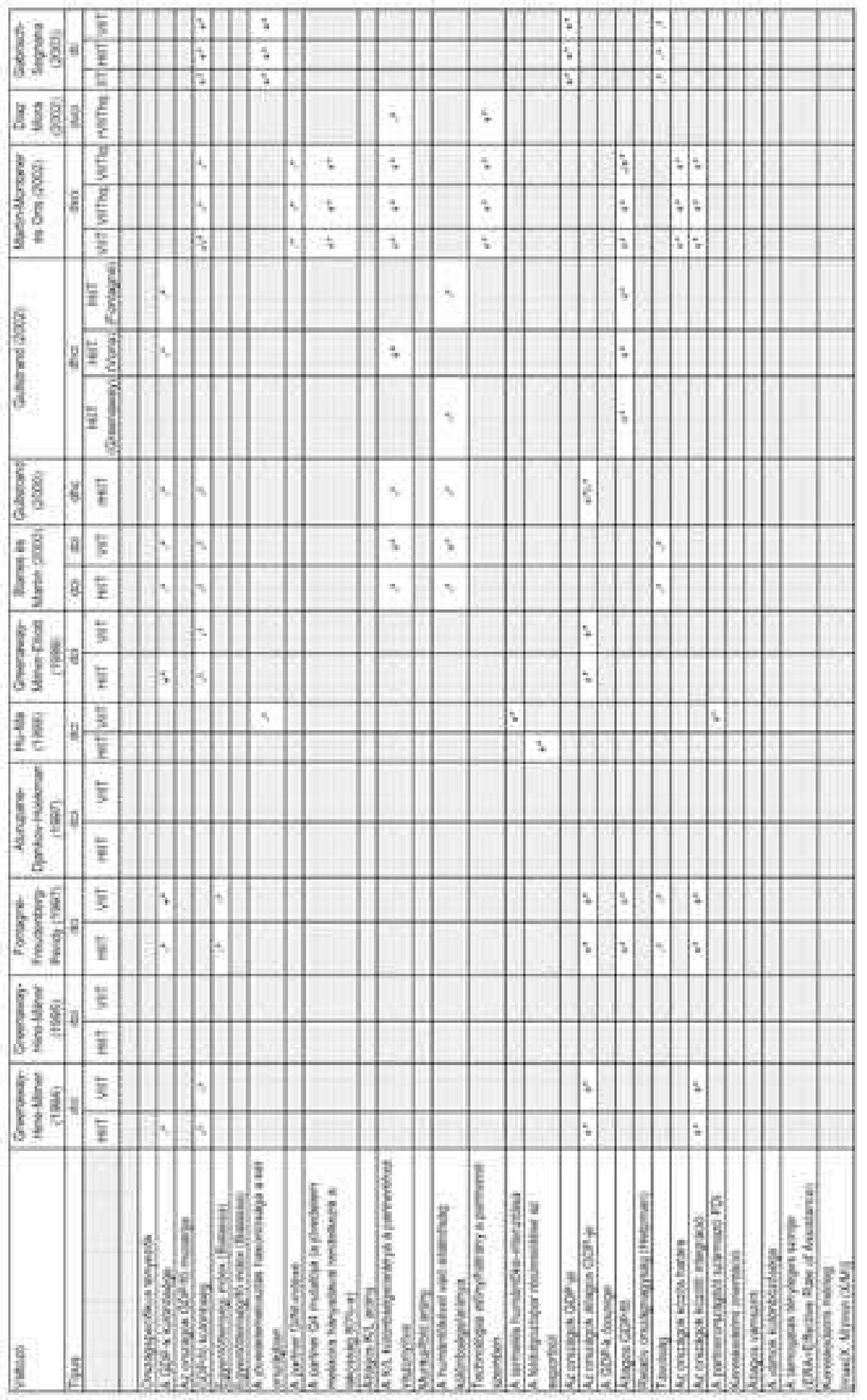


1/6b. tábla: A HIIT-t és VIIT-t elkülönítő vizsgálatok: ágazatspecifikus tényezők

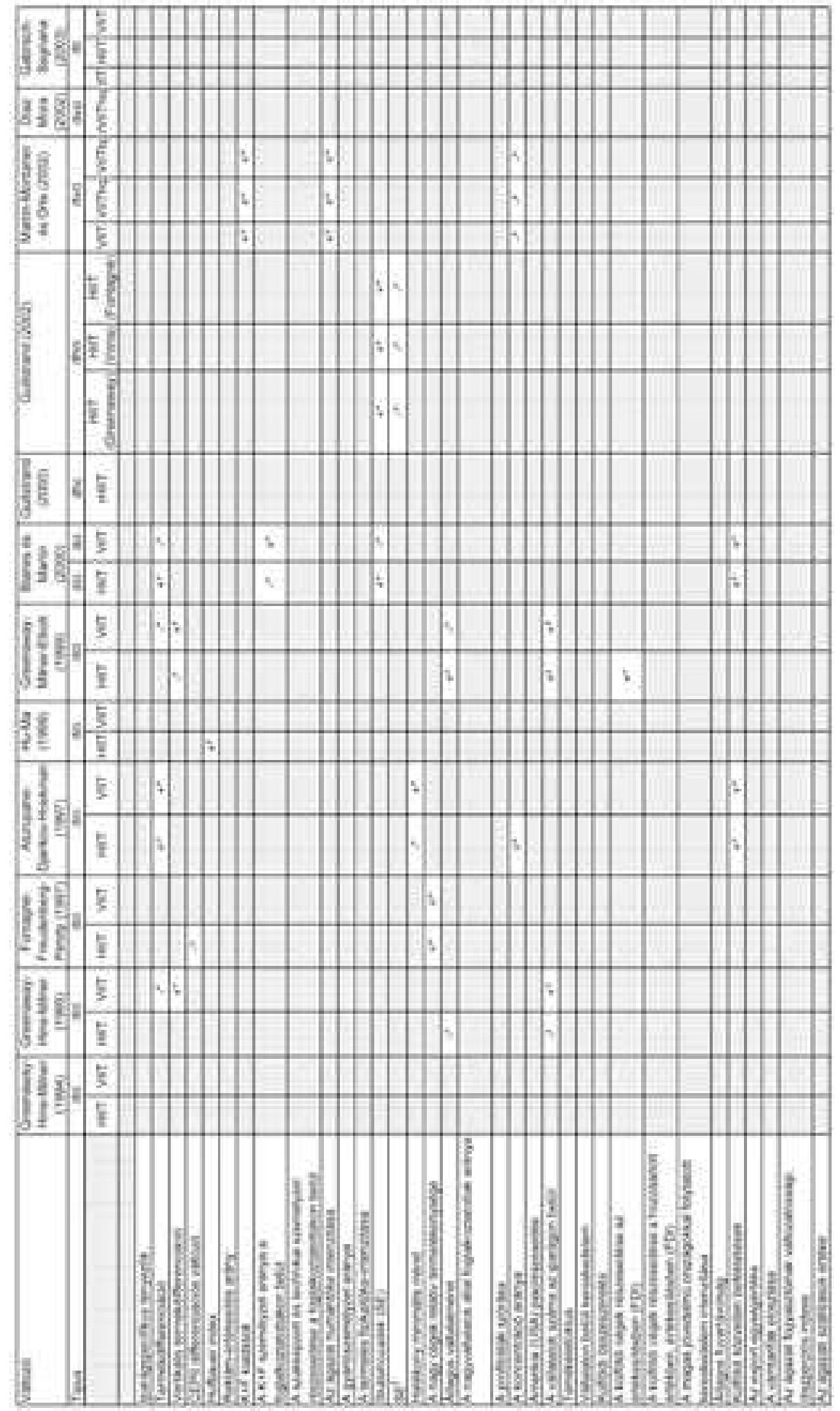

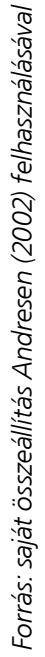




\section{Hivatkozások}

Andresen, M. A. (2002): Empirical Intra-Industry Trade: What We Know and What We Need to Know, mimeo, Department of Geography, University of British Columbia, Vancouver, Canada

Aturupane, C.-Djankov, S.-Hoekman B. (1997): Determinants of Intra-Industry Trade between East and West Europe, Centre for Economic Policy Research, Discussion Paper: 1721 (October)

Balassa, B. (1966): Tariff Reduction and Trade in Manufactures among the Industrial Countries, American Economic Review, Vol. 56(3), June, 466-473. o.

Balassa, B. (1986a): Intra-Industry Specialization: A Cross-Country Analysis, European Economic Review, Vol. 30(1), February, 27-42. o.

Balassa, B. (1986b): Intra-Industry Trade among Exporters of Manufactured Goods, in: Greenaway, D.-Tharakan P. K. M. (eds.): Imperfect Competition and International Trade: The Policy Aspects of Intra-Industry Trade, Brighton, Sussex: Harvestor Press, Wheatsheaf Books, 108-128. o.

Balassa, B.-Bauwens, L. (1987): Intra-Industry Specialization in a Multi-Country and Multi-Industry Framework, Economic Journal, Vol. 97(388), December, 923-939. o.

Balassa, B.-Bauwens, L. (1988): The Determinants ofIntra-European Trade in Manufactured Goods, European Economic Review, 32(7), September, 1421-1437. o.

Bergstrand, J. H. (1989): The generalized gravity equation, monopolistic competition, and the factor-proportions theory in international trade, Review of Economics and Statistics, Vol. 71(1), February, 143-153. o.

Bergstrand, J. H. (1990): The Hechscher-Ohlin-Samuelson Model, the Linder Hypothesis and the Determinants of Bilateral Intra-industry Trade, Economic Journal, Vol. 100(403), December, 1216-1229. o.

Bernhofen, D. M. (1999): Intra-Industry Trade and Strategic Interaction: Theory and Evidence, Journal of International Economics, Vol. 47(1), February, 223-244. o.

Bernhofen, D. M. (2001): Product differentiation, competition and international trade, Canadian Journal of Economics, Vol. 34(4), November, 1010-1023. o.

Blanes, J. V. C.-Martín, C. (2000): The Nature and Causes of Intra-Industry Trade: Back to the Comparative Advantage Explanation? The Case of Spain, Weltwirtschaftliches Archiv, Vol. 136(3), 423-441. o.

Brainard, S. L. (1993a): A Simple Theory of Multinational Corporations and Trade with a Trade-Off between Proximity and Concentration, NBER Working Paper No. 4269, February, National Bureau of Economic Research, Cambridge, MA

Brander, J. A. (1981): Intra-industry trade in identical commodities, Journal of International Economics, Vol. 11(1), February, 1-14. o.

Brander, J. A.-Krugman, P. (1983): A 'Reciprocal Dumping' Model of International Trade, Journal of International Economics, Vol. 15(3-4), November, 313-321. o.

Caves, R. E. (1981): Intra-Industry Trade and Market Structure in the Industrial Countries, Oxford Economic Papers, Volume 33(2), July, 203-223. o.

Celi, G. (1999): Vertical and Horizontal Intra-Industry Trade: What is the Evidence for the UK, Discussion Paper 49, June, Università degli Studi di Salerno, Centro di Economia del Lavoro e di Politica Economica 
Clark, D. P.-Stanley, D. L. (1999): Determinants of Intra-Industry Trade Between Developing Countries and the United States, Journal of Economic Development, Vol. 24(2), December, 79-95. o.

Cukrowski, J.-Aksen, E. (2003): Perfect competition and intra-industry trade, Economics Letters, Vol. 78(1), January, 101-108. o.

Culem, C.-Lundberg, L. (1986): The Product Pattern of Intra-Industry Trade: Stability among Countries and over Time, Weltwirtschaftliches Archiv, Vol. 122(1), 113-130. o.

Davis, D. R. (1995): Intra-Industry Trade: A Heckscher-Ohlin-Ricardo Approach, Journal of International Economics, Vol. 39(3-4), November, 201-226. o.

Deardorff, A. V. (1984): Testing Trade Theories and Predicting Trade Flows, in: Jones, R. W.-Kenen, P. B. (eds.): Handbook of International Economics, North-Holland, Amsterdam, New York, Oxford, Vol. 1., 467-517. o.

Díaz Mora, C. (2002): The Role of Comparative Advantage in Trade within Industries: A Panel Data Approach for the European Union, Weltwirtschaftliches Archiv, Vol. 138(2), 291-316. o.

Dixit, A.K.-Norman, V.(1980): TheoryofInternational Trade: A Dual, General Equilibrium Approach, London: Cambridge University Press

Drèze, J. (1960): Quelques Réflexions Sereines sur l'Adaptation de l'Industrie Belge au Marché Commun, Comptes-rendus des Travaux de la Société d'Economie Politique de Belgique, \#275

Drèze, J. (1961): Les exportations intra-C.E.E. en 1958 et la position Belge, Recherches Économiques de Louvain, Vol. 27., 717-738. o.

Eaton, J.-Kierzkowski, H. (1984): Oligopolistic Competition, Product Variety, and International Trade, in Kierzkowski, H. (ed.): Monopolistic Competition and International Trade, Oxford, Oxford University Press, 69-83. o.

Ethier, W. J. (1982): National and International Returns to Scale in the Modern Theory of International Trade, American Economic Review, Vol. 72(3), June, 389-405. o.

Falvey, R. E. (1981): Commercial Policy and Intra-Industry Trade, Journal of International Economics, Vol. 11(4), November, 495-511. o.

Falvey, R.E.-Kierzkowski, H.(1987): Product Quality, Intra-Industry Trade and(Im)Perfect Competition, In Kierzkowski H. (ed.): Protection and Competition in International Trade: Essays in Honor of W.M. Corden, Oxford University Press, 143-161. o.

Feenstra, R. C.-Markusen, J. R.-Rose, A. K. (2001): Using the gravity equation to differentiate among alternative theories of trade, Canadian Journal of Economics, Vol. 34(2), May, 430-447. o.

Flam, H.-Helpman, E. (1987): Vertical Product Differentiation and North-South Trade, American Economic Review, Vol. 77(5), December, 810-822. o.

Fontagné, L.-Freudenberg, M. (1997): Intra-Industry Trade Methodological Issues Reconsidered, CEPII, document de travail no. 97-01, Centre d'Etudes Prospectives et d'Informations Internationales, Paris

Fontagné, L.-Freudenberg, M. (2002): Long-term Trends in Intra-industry Trade, in: Lloyd, P. J.-Lee, H-H. (eds.): Frontiers of Research in Intra-industry Trade, Chapter 8.

Fontagné, L.-Freudenberg, M.-Péridy, N. (1997): Trade Patterns Inside the Single Market, CEPII, document de travail no. 97-07, Centre d'Etudes Prospectives et d'Informations Internationales, Paris 
Fontagné, L.-Freudenberg, M.-Péridy, N. (1998): Intra-Industry Trade and the Single Market: Quality Matters, CEPR Discussion Paper 1959.

Gabrisch, H.-Segnana, M. L. (2003): Vertical and Horizontal Patterns of Intra-Industry Trade between EU and Candidate Countries, Final report of a study that contributes to the research project 'EU Integration and the Prospects for Catch-Up Development in CEECs. The Determinants of the Productivity Gap' by the European Union under Framework Programme 5., Halle

Gabszewicz, J. J.-Shaked, A.-Sutton, J.-Thisse, J-F. (1981): International Trade in Differentiated Products, International Economic Review, Vol. 22(3), October, 527-534. o. Gabszewicz, J. J.-Thisse, J-F. (1979): Price Competition, Quality and Income Disparities, Journal of Economic Theory, Vol. 2(3), June, 340-359. o.

Gabszewicz,J.-Turrini,A.(1997): Workers'Skills, ProductQualityandIndustryEquilibrium, International Journal of Industrial Organization, Vol. 18(4), May, 575-593. o.

Greenaway, D.-Hine, R.-Milner, C. (1994): Country-specific factors and the pattern of horizontal and vertical intra-industry trade in the UK, Weltwirtschaftliches Archiv, Vol. 130(1), 77-100. o.

Greenaway, D.-Hine, R.-Milner, C. (1995): Vertical and Horizontal Intra-Industry Trade: A Cross Industry Analysis for the United Kingdom, Economic Journal, Vol. 105(433), November, 1505-1518. o.

Greenaway, D.-Milner, C. (1984): A Cross Section Analysis of Intra-Industry Trade in the U.K., European Economic Review, Vol. 25(3), August, 319-344. o.

Greenaway, D-Milner, C.-Elliott, R. (1999): UK Intra-Industry Trade with the EU North and South, Oxford Bulletin of Economics and Statistics, Vol. 61(3), August, 365-384. o. Grubel, H. G. (1967): Intra-Industry Specialization and the Pattern of Trade, Canadian Journal of Economics and Political Science, Vol. 33(3), August, 374-388. o.

Grubel, H. G.-Lloyd, P. (1975): Intra-industry Trade: The Theory and Measurement of International Trade in Differentiated Products, London, The Macmillan Press

Guba Ferenc Zoltán (2000): Transzferek és hatékonyságzavarok az élelmiszer-termékpályákon, Ph. D. értekezés, Budapesti Közgazdaságtudományi és Államigazgatási Egyetem, Agrárközgazdasági Ph. D. program

Gullstrand, J. (2000): Deconstructing Intra-Industry Trade With Special Reference to EU-Trade, paper presented at European Trade Study Group (ETSG) Second Annual Conference, Glasgow, 15-17 September, 2000., University of Glasgow

Gullstrand, J. (2002): Does the Measurement of Intra-Industry Trade Matter?, Weltwirtschaftliches Archiv, Vol. 138(2), 317-339. o.

Haucap J.-Wey, C.-Barmbold, J. (2000): Location costs, product quality and implicit franchise contracts, Journal of International Economics, Vol. 52(1), October, 69-87. o.

Havrylyshyn, O.-Kunzel, P. (1997): Intra-Industry Trade of Arab Countries: An Indicator of Potential Competitiveness, IMF Working Paper, WP/97/47

Helpman,E.(1981):International Tradein thePresenceofProductDifferentiation, Economies of Scale and Monopolistic Competition: A Chamberlin-Heckscher-Ohlin Approach, Journal of International Economics, Vol. 11(3), August, 305-340. o.

Helpman, E. (1983): International trade in differentiated middle products, in: Hague, D.-Jugenfelt, K. (eds.): Structural adjustment in developed open economies, St. Martin's Press, New York, 3-23. o. 
Helpman, E. (1985): Multinational Corporations and Trade Structure, Review of Economic Studies, Vol. 52(3), July, 443-457. o.

Helpman, E. (1987): Imperfect Competition and International Trade: Evidence from Fourteen Industrialized Countries, Journal of Japanese and International Economics, Vol.1(1), March, 62-81. o.

Helpman, E. (1999): The Structure of Foreign Trade, Journal of Economic Perspectives, Vol. 13(2), Spring, 121-144. o..

Helpman, E.-Krugman, P. (1985): Market Structure and Foreign Trade: Increasing Returns, Imperfect Competition, and the International Economy, MIT Press, Cambridge.

Horstmann, I. J.-Markusen, J. R. (1987): Strategic Investments and the Development of Multinationals, International Economic Review, Vol. 28(1), February, 109-121. o.

Horstmann, I. J.-Markusen, J. R. (1992): Endogenous Market Structure in International Trade (Natura Facit Saltum), Journal of International Economics, Vol. 32(1-2), February, 109-129. o.

Hu, X.-Ma, Y. (1999): International Intra-Industry Trade of China, Weltwirtschaftliches Archiv, Vol. 135(1), January, 82-101. o.

Hufbauer, G. C. (1970): The Impact of National Characteristics and Technology on the Commodity Composition of Trade in Manufactured Products, in: Vernon, R. (ed.): The Technology Factor in International Trade, New York, National Bureau of Economic Research.

Hughes, K. (1993): Intra-Industry Trade in the 1980s: A Panel Study, Weltwirtschaftliches Archiv, Vol. 129(3), 561-572. o.

Hummels, D.-Levinsohn, J. (1995): Monopolistic Competition and International Trade: Reconsidering the Evidence, Quarterly Journal of Economics, Vol. 110(3), August, 799836. o.

IMF (2002): World Economic Outlook, September 2002, Trade and Finance, Washington, D. C.

Krugman, P. (1979): Increasing Returns, Monopolistic Competition, and International Trade, Journal of International Economics, Vol. 9(4), November, 469-479. o.

Krugman, P. (1980): Scale Economies, Product Differentiation, and the Pattern of Trade, American Economic Review, Vol. 70(5), December, 950-959. o.

Krugman, P. (1981): Intra-Industry Specialization and the Gains from Trade, Journal of Political Economy, Vol. 89(5), October, 959-973. o.

Lancaster, K. J. (1980): Intra Industry Trade Under Perfect Monopolistic Competition, Journal of International Economics, Vol.10(2), May, 151-175. o.

Lancaster, K. J. (1979): Variety, Equity and Efficiency, Columbia University Press, New York

Leamer, E. E. (1992): Testing trade theory, NBER Working Paper No. 3957, January, National Bureau of Economic Research, Cambridge, MA

Leontief, W. W. (1953): Domestic Production and Foreign Trade: The American Capital Position Re-Examined, Proceedings of the American Philosophical Society, Vol. 97(4), September, 332-349. o.

Linder, S. B. (1961): An Essay on Trade and Transformation, John Wiley \& Sons, New York.

Loertscher, R.-Wolter, F. (1980): Determinants of Intra-Industry Trade Among Countries and Across Industries, Welwirtschaftliches Archiv, Vol. 116(2), 280-293. o. 
Lutz, S.-Turrini, A. (1999): Skills, Labour Costs, and Vertically Differentiated Industries: a General Equilibrium Analysis, ZEI Working Paper, B99-26

Lüthje, T. (2001): Intraindustry Trade in Intermediate Goods, International Advances in Economic Research, Vol. 7(4), November, 393-408. o.

Markusen, J. R. (1995): The Boundaries of Multinational Enterprises and the Theory of International Trade, Journal of Economic Perspectives, Vol. 9(2 ), Spring, 169-189. o.

Markusen, J. R.-Venables, A. J. (1998): Multinational Firms and New Trade Theory, Journal of International Economics, Vol. 46(2), December, 183-203. o.

Markusen, J. R.-Venables, A. J. (2000): The Theory of Endowment, Intra-industry and Multinational Trade, Journal of International Economics, Vol. 52(2), December, 209234. o.

Martín-Montaner,J.A.-Orts, V.(2002):ComercioIntra-IndustrialEspa-ol:Especialización Vertical y Ventaja Comparativa, Revista de Economía Aplicada, Vol. 10(30), 25-51. o.

Matsuyama, K. (2000): A Ricardian Model with a Continuum of Goods under Nonhomothetic Preferences: Demand Complementarities, Income Distribution, and North-South Trade, Journal of Political Economy, Vol. 108(6), December, 1093-1120. o.

Motta, M. (1992): Sunk Costs and Trade Liberalisation, Economic Journal, Vol. 102(412), May, 578-587. o.

Motta, M. (1993): Endogenous Quality Choice: Price vs. Quantity Competition, Journal of Industrial Economics, Vol. 41(2), June, 113-131. o.

Motta, M. (1994): International Trade and investment in a vertically differentiated industry, International Journal of Industrial Organization, Vol. 12(2), June, 179-196. o.

Schmitt, N.-Yu, Z. (2001): Horizontal Intra-Industry Trade and the Growth of International Trade, Leverhulme Centre for Research on Globalisation and Labour Markets, Research Paper 2001/10, School of Economics, University of Nottingham

Shaked, A.-Sutton J. (1987): Product Differentiation and Industrial Structure, Journal of Industrial Economics, Vol. 36(2), December, 131-146. o.

Shaked, A.-Sutton, J. (1982): Relaxing Price Competition Through Product Differentiation, Review of Economic Studies, Vol. 49(1), January, 3-13. o.

Shaked, A-Sutton, J. (1984): Natural Oligopolies and International Trade, in: Kierzkowski, H. (ed.) Monopolistic Competition and International Trade, Oxford University Press, Oxford, 34-50. o.

Sharma, K. (2000): The Pattern and Determinants of Intra-Industry Trade in Australian Manufacturing, The Australian Economic Review, Vol. 33(3), September, 245-255. o.

Stokey, N. L. (1991): The Volume and Composition of Trade Between Rich and Poor Countries, Review of Economic Studies, Vol. 58(1), January, 63-80. o.

Sutton, J. (1991): Sunk Costs and Market Structure: Price Competition, Advertising, and the Evolution of Concentration, MIT Press, Cambridge, Massachusetts, and London

Tharakan, P. K. M. (1984): Intra-industry Trade between the Industrial Countries and the Developing World, European Economic Review, Vol. 26(1-2), October-November, 213227. o.

Toh, K. (1982): A Cross-Section Analysis of Intra-Industry Trade in U.S. Manufacturing Industries, Weltwirtschaftliches Archiv, Vol. 118(2), 281-301. o.

Torstensson, J. (1996): Determinants of Intra-Industry Trade: A Sensitivity Analysis, Oxford Bulletin of Economics and Statistics, Vol. 58(3), August, 507-524. o. 
Venables, A. J. (1985): Trade and Trade Policy with Imperfect Competition: the Case of Identical Products and Free Entry, Journal of International Economics, Vol. 19(1-2), August, 1-19. o.

Venables, A. J. (1994): Integration and the Export Behavior of Firms: Trade Costs, Trade Volumes and Welfare, Weltwirtschaftliches Archiv, Vol. 130(1), 118-132. o.

Verdoorn, P. J. (1960): The Intra-Block Trade of Benelux, In: Robinson, E. A. G. (ed.)

Economic Consequences of the Size of Nations. Macmillan, London., 327-368. o.

Vernon, R. (1966): International investment and international trade in the product life cycle, Quarterly Journal of Economics, Vol. 80(2), 190-207. o.

Weinstein, D. E. (1992): Competition and Unilateral Dumping, Journal of International Economics, Vol. 32(3-4), May, 379-388. o.

Zhigang, Z. (1999): Determinants of China's Intra-Industry Trade in Manufactures (1984-1994): A Tobit cum Fixed Effect Panel Data Model Application, Paper presented at International Workshop: "International Trade, Industrial Organization, and Asia", City University of Hong Kong, Hong Kong, August 2-6, 1999. 